\title{
Metagenomic analysis of viruses associated with maize lethal necrosis in Kenya
}

\author{
Mwathi Jane Wamaitha" ${ }^{*}$, Deepti Nigam², Solomon Maina ${ }^{3,4}$, Francesca Stomeo ${ }^{5}$, Anne Wangai ${ }^{1}$, \\ Joyce Njoki Njuguna ${ }^{5}$, Timothy A. Holton ${ }^{6}$, Bramwel W. Wanjala ${ }^{5}$, Mark Wamalwa ${ }^{5}$, Tanui Lucas $^{1}$, \\ Appolinaire Djikeng ${ }^{5,7}$ and Hernan Garcia-Ruiz $2^{*}$ (D)
}

\begin{abstract}
Background: Maize lethal necrosis is caused by a synergistic co-infection of Maize chlorotic mottle virus (MCMV) and a specific member of the Potyviridae, such as Sugarcane mosaic virus (SCMV), Wheat streak mosaic virus (WSMV) or Johnson grass mosaic virus (JGMV). Typical maize lethal necrosis symptoms include severe yellowing and leaf drying from the edges. In Kenya, we detected plants showing typical and atypical symptoms. Both groups of plants often tested negative for SCMV by ELISA.

Methods: We used next-generation sequencing to identify viruses associated to maize lethal necrosis in Kenya through a metagenomics analysis. Symptomatic and asymptomatic leaf samples were collected from maize and sorghum representing sixteen counties.

Results: Complete and partial genomes were assembled for MCMV, SCMV, Maize streak virus (MSV) and Maize yellow dwarf virus-RMV (MYDV-RMV). These four viruses (MCMV, SCMV, MSV and MYDV-RMV) were found together in 30 of 68 samples. A geographic analysis showed that these viruses are widely distributed in Kenya. Phylogenetic analyses of nucleotide sequences showed that MCMV, MYDV-RMV and MSV are similar to isolates from East Africa and other parts of the world. Single nucleotide polymorphism, nucleotide and polyprotein sequence alignments identified three genetically distinct groups of SCMV in Kenya. Variation mapped to sequences at the border of NIb and the coat protein. Partial genome sequences were obtained for other four potyviruses and one polerovirus.

Conclusion: Our results uncover the complexity of the maize lethal necrosis epidemic in Kenya. MCMV, SCMV, MSV and MYDV-RMV are widely distributed and infect both maize and sorghum. SCMV population in Kenya is diverse and consists of numerous strains that are genetically different to isolates from other parts of the world. Several potyviruses, and possibly poleroviruses, are also involved.
\end{abstract}

Keywords: Maize lethal necrosis, MCMV, SCMV, MYDV-RMV, MSV, Metagenomics, Phylogenetics, Coat protein variation

\section{Background}

Maize (Zea mays L.) is one of the most important cereals in Sub-Saharan Africa and is grown in approximately 25 million hectares [1]. Maize is consumed as a preferred calorie source by $95 \%$ of the population, at an average of $1075 \mathrm{kcal} / \mathrm{capita} /$ day, which represents more than $50 \%$ of the recommended daily

\footnotetext{
* Correspondence: jane.wamaitha@hotmail.com; hgarciaruiz2@unl.edu ${ }^{1}$ Kenya Agricultural and Livestock Research Organization (KALRO), P. O. Box 14733-00800, Nairobi, Kenya

2Department of Plant Pathology and Nebraska Center for Virology, University of Nebraska- Lincoln, Lincoln, NE 68583, USA

Full list of author information is available at the end of the article
}

intake [2]. Maize production is destined for human consumption or animal feed at a proportion of 88 and $12 \%$, respectively $[3,4]$.

In 2011 maize lethal necrosis disease was first detected in Kenya [5-7], and confirmed in several countries in East and Central Africa, specifically in Tanzania, Uganda [8], Rwanda [9] DR Congo [10], Ethiopia and South Sudan [11]. Corn lethal necrosis (CLN) was first described in the State of Kansas in 1978 [12]. In their original descriptions, corn lethal necrosis and maize lethal necrosis defined the same disease. Herein we use maize lethal necrosis disease.

(C) The Author(s). 2018 Open Access This article is distributed under the terms of the Creative Commons Attribution 4.0 International License (http://creativecommons.org/licenses/by/4.0/), which permits unrestricted use, distribution, and 
In Sub-Saharan Africa, smallholder farms account for approximately $80 \%$ of the farm land and employ 175 million people directly $[13,14]$. Small-scale farmers largely rely on maize, as a major source of energy and revenue [15]. With yield losses ranging from 30 to $100 \%$ that lead to food shortages and contribute to hunger and malnutrition [16], maize lethal necrosis is currently a threat to maize production and food security in Sub-Saharan Africa.

Maize lethal necrosis is caused by a synergistic coinfection of MCMV, a Machlomovirus in the family Tombusviridae [17], and specific members of the family Potyviridae, such as SCMV [12], Wheat streak mosaic virus (WSMV) [18], or JGMV [19]. In maize lethal necrosis outbreaks, MCMV and SCMV is the most prevalent virus combination $[9,10,20]$. In Rwanda, Maize yellow mosaic virus (MaYMV), a polerovirus, was recently detected in maize plants showing symptoms similar to those caused by maize lethal necrosis [21].

Typical maize lethal necrosis symptoms include severe yellowing and leaf drying from the edges, stunting and premature plant death, sterility in male plants, poor tasseling, lack of or only a few grains in the cob, malformed or rotten cobs $[7,19]$. In farmer's fields in Kenya, we detected plants showing bright yellow stripes with green edges, which deviate from typical maize lethal necrosis symptoms. Additionally, symptomatic plants often tested negative for SCMV by ELISA, as described by others $[19,21,22]$.

Maize lethal necrosis continues to spread rampantly and is a major concern to maize stakeholders [5] including small and large-scale farmers, commercial seed sector, millers, transporters, policy makers, local and international communities. These raises several questions such as why is maize lethal necrosis still difficult to manage and what strategies can farmers implement?

Natural and engineered genetic resistance provide a successful approach to managing viral diseases [23]. With respect to natural genetic resistance, massive screens of commercial hybrids and thousands of maize lines reported high levels of susceptibility. Only few lines were moderately resistant $[24,25]$. Several efforts are underway to identify and characterize maize resistance to MCMV [26] and SCMV [27].

We hypothesized that uncharacterized viruses synergistically interact with MCMV to cause maize lethal necrosis, and there is genetic variation between SCMV and MCMV in East Africa compared to the rest of the world. To test these hypotheses, we collected samples from symptomatic and asymptomatic maize leaves in sixteen counties in Kenya. Cultivated and wild sorghum [Sorghum bicolor (L.) Moench] and napier grass (Pennisetum purpureum S.) were also included to determine their potential as alternate hosts. Viruses present were identified by metagenomics using next-generation sequencing of total RNA and bioinformatics. Viral presence was determined for each individual sample using de-novo assembled contigs.

After de-novo assembly, complete and partial genomes were obtained for MCMV, SCMV, Maize yellow dwarf virus-RMV (MYDV-RMV) and Maize streak virus (MSV). Partial genomes were assembled for other four potyviruses and one polerovirus. A geographic analysis showed the wide distribution of MCMV, SCMV, MYDV-RMV and MSV infecting maize and sorghum in Kenya. A large number (30/68) of the samples analyzed had a combination of four viruses: MCMV, SCMV, MYDV-RMV, and MSV. Only one sample had MCMV in the absence of other viruses. All the other samples (67/68) had MCMV plus one, two, three, or four other viruses. Phylogenetic analyses of near complete genome nucleotide sequences showed that MCMV, MSV and MYDV-RMV in Kenya are similar to isolates from East Africa. In contrast, SCMV from Kenya exhibits the largest genetic variation and distance with respect to isolates from others parts of the world, including East Africa. These results provide a solid foundation to develop virus diagnostic protocols, management strategies, and raise the possibility of a synergistic interaction between MCMV and a polerovirus to cause maize lethal necrosis.

\section{Methods}

\section{Sample collection}

Between 2012 and 2014 leaf samples (0.5 g) of maize, sorghum or napier grass were collected at vegetative stage from farmer's fields in sixteen counties in Kenya (Fig. 1). At the time of tissue collection, some plants were asymptomatic and others were symptomatic (Fig. 1a). The symptomatic plants ranged from yellow spotting (early-stage), streaking (mid-stage) or necrosis of the leaf margin (latestage). In some cases, both, asymptomatic (20) and symptomatic (48) samples were collected from the same farm or nearby. Counties included in the sampling were selected based on yield losses caused by maize lethal necrosis $(30-100 \%)[7,11,20]$, and were classified as maize lethal necrosis hotspots (Bomet, Narok, Nandi, Nyamira and Busia), moderate-severe hotspots (Homabay, Transzoia, Migori, Siaya, Uasin Gishu, Kisumu, Elgeyo Marakwet and Kericho) and low-medium hotspots (Embu, Kakamega and Kirinyaga). Samples were frozen in liquid nitrogen and transported to Kenya Agricultural and Livestock Research Organization (KALRO) Kabete, and stored at $-80{ }^{\circ} \mathrm{C}$ until processed.

\section{Geographic distribution}

Geographic coordinates (latitude and longitude) of the 68 sample locations were marked by Global Positioning System (GPS) and linked to viruses found. Data was converted into GIS using ARCGIS 10.4. Geographical 


\section{a Representative plants}

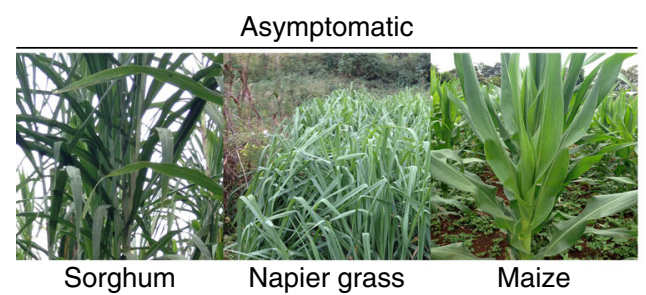

Symptomatic

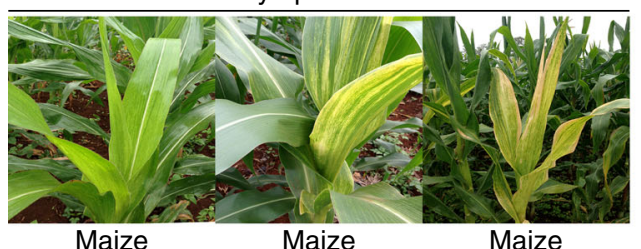

\section{Frequency of mixed infections}

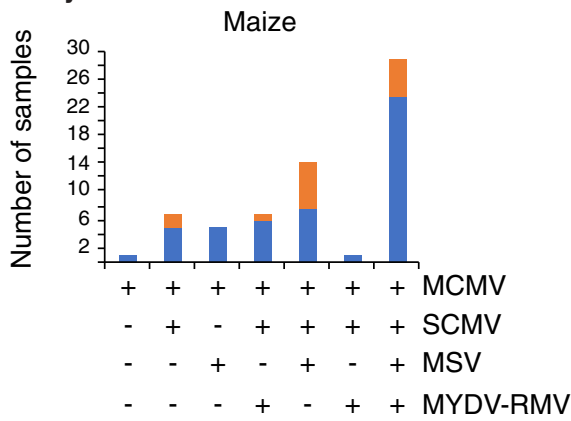

b Distribution of maize viruses in Kenya
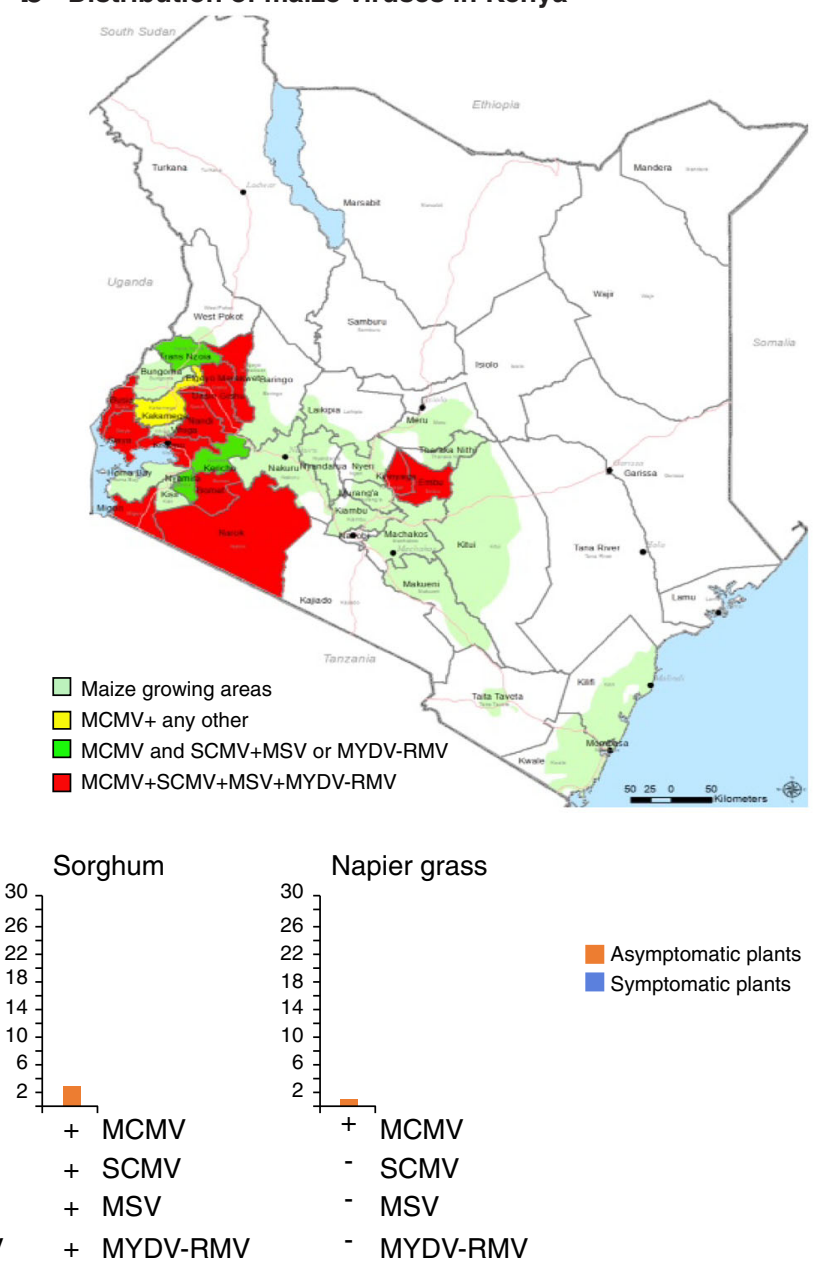

d Other viruses

\begin{tabular}{|c|c|c|c|c|c|c|c|c|}
\hline Virus & $\begin{array}{l}\text { Reference } \\
\text { Accession }\end{array}$ & $\begin{array}{l}\text { Length } \\
\text { (bp) }\end{array}$ & $\begin{array}{r}\text { Con } \\
\text { Number }\end{array}$ & Length (bp) & $\begin{array}{l}\text { Similarity } \\
(\%)\end{array}$ & E-value & $\mathrm{n}$ & $\begin{array}{l}\text { Sample } \\
\text { number }\end{array}$ \\
\hline Hubei Poty-like virus $1^{*}$ & NC_032912.1 & 9356 & 41 & 203 to 9323 & 75.2 to 87.3 & $<3.6 \mathrm{E}-30$ & 19 & $\begin{array}{l}6,14,17,20,23,24,25 \\
27,30,32,34,35,40,41 \\
48,66,67,68,72\end{array}$ \\
\hline Barley virus $\mathrm{G}$ isolate Gimje* & NC_029906.1 & 5620 & 26 & 242 to 5494 & 80.0 to 87.6 & $<4.9 \mathrm{E}-65$ & 11 & $\begin{array}{l}18,29,30,32,33,37 \\
40,41,42,44,45\end{array}$ \\
\hline Scallion mosaic virus* & NC_003399.1 & 9324 & 9 & 260 to 961 & 71.6 to 90.0 & $<1.8 \mathrm{E}-09$ & 7 & $14,20,23,28,46,47,68$ \\
\hline Jhonson grass mosaic virus ${ }^{\star}$ & NC_003606.1 & 9779 & 6 & 244 to 1630 & 75.0 to 84.0 & $<4.4 \mathrm{E}-20$ & 5 & $17,18,29,30,46$ \\
\hline $\begin{array}{l}\text { Iranian johnsongrass } \\
\text { mosaic virus* }\end{array}$ & NC_018833.1 & 9544 & 2 & 244 to 332 & 75.0 to 80.0 & $<4.4 \mathrm{E}-25$ & 2 & 26,36 \\
\hline
\end{tabular}

Fig. 1 Geographic distribution of maize-infecting viruses in Kenya. a Representative pictures of asymptomatic and symptomatic plants sampled in this study. $\mathbf{b}$ Maize-growing areas and distribution of the main maize viruses detected in this study. Counties are color-coded to illustrate the combinations of viruses found. c Most abundant viruses detected and frequency of mixed infections in asymptomatic and symptomatic plants (68 samples total). $\mathbf{d}$ Other viruses detected in this study. Potyvirus and polerovirus are denoted by * and **, respectively. Reference accession number and length are provided. Number of de-novo assembled contigs, range of length and similarity to the reference genome is provided. Identity of samples contributing at least one contig is indicated 
distribution of the samples collected and the viruses found (68 data points for 68 samples) was constructed by overlaying the layer of sample points with that of the maize growing zones within Kenya forming the background layer. Counties sampled were color-coded based on the combinations of viruses found (Fig. 1b). The samples were identified by county of origin a consecutive number (3 through 72).

\section{Total RNA extraction}

RNA was extracted from $0.1 \mathrm{~g}$ of leaf tissue using ZR Plant RNA MiniPrep ${ }^{\text {Ts }}$ (Catalog No. R2024) according to the manufactures instructions. In brief, tissue was ground with a pestle and mortar containing $800 \mu \mathrm{L}$ lysis buffer in a ZR BashingBead ${ }^{\text {tw }}$ Lysis tube. The mixture was centrifuged at $\geq 12,000 \times \mathrm{g}$ for $1 \mathrm{~min}$ at $4{ }^{\circ} \mathrm{C}$, and $400 \mu \mathrm{L}$ of the supernatant was transferred to a Zymo$\operatorname{spin}^{\text {tw }} 111 \mathrm{C}$ column in a collection tube, and centrifuged for a further $8000 \mathrm{x} \mathrm{g}$ for $30 \mathrm{~s}$. The RNA flow-through was washed with $320 \mu \mathrm{L}$ of ethanol (95-100\%), and centrifuged at $\geq 12,000 \times \mathrm{g}$ for $30 \mathrm{~s}$ in a Zymo-spin ${ }^{\text {rm }} 11 \mathrm{C}$ collection tube. The RNA was re-suspended in $400 \mu \mathrm{L}$ RNA prep buffer, centrifuged at $12,000 \mathrm{x}$ g for $30 \mathrm{~s}$, washed with RNA Wash buffer, and eluted with $30 \mu \mathrm{L}$ of DNase/RNAses free water. A NanoDrop spectrophotometer was used to measure the RNA concentration at maximum absorbance of $260 \mathrm{~nm}$, and the purity was assessed by measuring the $260 / 280$ and $260 / 230$ absorbance ratios. Using a Qubit 2.0 the concentration ranged from $100 \mathrm{ng} / \mu \mathrm{L}$ to $300 \mathrm{ng} / \mu \mathrm{L}$ and one microgram was run on a $1.5 \%$ agarose gel $(70 \mathrm{~V}$ for $60 \mathrm{~min})$. Total RNA was stored at $-80^{\circ} \mathrm{C}$.

\section{Library construction for next generation sequencing}

Total RNA (1 $\mu \mathrm{g}$ per library) was used as the template to construct paired-end (PE) indexed Illumina libraries according to TruSeq RNA Library Preparation kit v2 (Illumina, San Diego, California) with modifications. To allow unbiased detection of polyadenylated and nonpolyadenylated virus genomes [28, 29], oligo-dT purification was not performed. RNA fragmentation was done with Illumina fragment mix added to $19.5 \mu \mathrm{L}$ of total RNA to make a volume of $70 \mu \mathrm{L}$. First strand cDNA was obtained using random hexamers and Superscript II reverse transcriptase. After double strand cDNA synthesis, ends were repaired by incubating in End Repair mix at $30{ }^{\circ} \mathrm{C}$ for $30 \mathrm{~min}$. The End Repair mix contains $3^{\prime}$ to $5^{\prime}$ exonuclease to remove the $3^{\prime}$ overhangs while the polymerase activity filled in the $5^{\prime}$ overhangs. Thereafter, $3^{\prime}$ ends were adenylated and adaptors ligated to the $5^{\prime}$ (flow cell binding sequences) and $3^{\prime}$ end (barcode indexed adapters). The dsDNA was enriched by 15 PCR cycles at $98{ }^{\circ} \mathrm{C}$ for $30 \mathrm{~s}$. Amplicon size and concentration of each library was verified using Qubit 2.0 and
Bioanalyzer (RIN > 8) (Agilent 2000) (Agilent, Santa Clara, CA. USA). Barcoded libraries were normalized and pooled for multiplex sequencing. A pooled barcoded library (ten nanomolar) consisted of 24 biological samples, each at equal molar concentration. Libraries were sequenced in the Illumina MiSeq System using a $2 \times 251$ v2 kit including a $1 \%$ PhiX v 3 spike to generate paired-end reads (Illumina). Three flow cells were used, each for one pool of samples and $5 \mu$ l were loaded per lane. The sequencing was performed using Illumina MiSeq at the Biosciences Eastern and Central AfricaInternational Livestock Research Institute (BecA-ILRI) Hub in Nairobi, Kenya.

\section{RNA sequence processing and de novo assembly}

Paired-end reads were de-multiplexed into individual samples using custom scripts at Biosciences Eastern and Central Africa-International Livestock Research Institute (BecA-ILRI) Hub, Nairobi, Kenya. Downstream bioinformatic analysis was done on high performance computing nodes at the Holland Computing Center (https://hcc.unl. edu) at the University of Nebraska-Lincoln. Sequence files were converted to fasta format, reads were evaluated using FastQC v0.11.2 [30], trimmed and filtered using Trimmomatic v0.36 [31] to remove adapter sequences, poly- $\mathrm{N}(\geq 10 \%)$ and low quality reads $(\mathrm{Q} \leq 5)$. Simultaneously, Q30, GC-content and sequence duplication levels of the reads were calculated. For each individual sample, high-quality reads with a Phred score of 64, denoting high quality base calls were de novo assembled into contigs using Trinity v2.4.0 with Kmer size $=25$ and other default parameters [32]. Contigs $\geq 200$ bp were used for virus identification through BlastN (Additional file 1: Figure S1).

Alignment of the nearly complete genome contigs against their reference genomes was performed using Bowtie V2 under default parameters. Bam files were made for the resulting alignments. Samtools [33] and bcftools, with the criteria of MAPQ score $>10$ and depth $\geq 3$ for each read were used to generate a consensus sequence for each virus species or for a group of samples within a virus species. Visualizations were made using Integrative Genomic Viewer (v2.4.4) [34].

\section{Virus identification}

BlastN was performed using de novo assembled contigs against a local Plant Virus Genome Database (PVGDB) containing 2166 plant virus genomes (http://www.ncbi. nlm.nih.gov/genome/viruses) (downloaded October 20, 2017) and the National Centre for Biotechnology Information (NCBI) "nr" databases. The cutoff was set at Evalue $\leq 1 \times 10^{-5}$. The top accession, based on sequence similarity was obtained for each one of the contigs in our samples and used for virus identification. For each 
viral species, the most frequent accession was used as reference for alignment and to estimate sequence similarity. A virus was determined as present in a sample if at least one contig $\geq 200$ bp with similarity $\geq$ $75 \%$ was detected (Additional file 1: Figure S1). Contigs matching viruses with lower similarity were not taken into consideration. Sequences not matching to any known virus or to the host were not analyzed further.

\section{Virus coverage maps}

For each virus identified, a representative sample yielding a genome-length contig was chosen to determine read depth against reference genome sequences (MCMV, X14736.2; SCMV, JX188385.1; MSV, AF329878.1; and MYDV-RMV, MF974579.2). Reads were mapped onto each virus genome using Bowtie V2 [33]. The coverage indicates the percentage of the genome area covered by an average of three reads [35], while read depth refers to the number of reads covering the same sequence. Integrative Genomic Viewer (v2.4.4) was used for Graphical alignment visualization [34].

\section{Multiple sequence alignment and phylogenetic analyses} Sequences from NCBI (MCMV, SCMV, MSV and MYDV-RMV) used as reference were selected based on a combination of sequence identity (>90\%) and sequence coverage. For each virus individual contigs were aligned using multiple sequence alignment program for nucleotides and proteins (MAFFT, v7) using default parameters (http://mafft.cbrc.jp/alignment/server/phylogeny.html) [36]. Phylogenetic trees were generated as described [37]. Briefly, SplitsTree4 (http://www. splitstree.org) was used to generate splits networks, using the default settings. Distances were estimated by uncorrected $\mathrm{P}$ (match option for ambiguous bases) and network made by neighbour-net [38]. Further, to produce phylogenetic trees two runs of four Monte Carlo Markov Chain (MCMC) computations were run for 1,000,000 generations under a General-Time-Reversible (GTR) model with a gamma distribution of rate variation between sites Bayesian inference in MrBayes 3.2 [39]. Convergence and effective sample size were examined using Tracer to confirm that estimated sample sizes for each parameter exceeded 200, as recommended by the MrBayes manual. For each virus, the consensus trees and Bayesian posterior probability values at nodes were calculated with a $10 \%$ burn-in removed from each run.

\section{SCMV single nucleotide polymorphism}

A single nucleotide polymorphism (SNP) analysis was done on the twenty samples with single contigs near complete SCMV genome. Illumina paired-end reads for each one of the samples were mapped against the SCMV reference genome (JX188385.1) using the BWA-mem option within BWA aligner (http://bio-bwa.sourceforge. net). To separate sequencing error from genomic variation, only reliable mapped reads were considered for SNP calling and unmapped reads were discarded. SNP positions within mapped reads were determined using samtools. VCFtools (http://vcftools.sourceforge.net) was used on the raw Variant Calling Format (VCF) files for the minimum depth (DP) 10 and SNP quality (Q) 30 to get high-quality SNPs. SNPs count was calculated using a $50 \mathrm{nt}$ interval with the SNP density option within the VCFtools, and the plot generated in Excel.

\section{Results}

\section{Identification of maize-infecting viruses}

To gain insight on viruses associated with maize lethal necrosis and their genetic variation in Kenya, we conducted a metagenomics analysis based on nextgeneration RNA sequencing, de-novo assembly and identification of viruses in Kenya (Fig. 1b) through bioinformatics. Total RNA was used to construct paired-end reads from 68 individual samples representing sixteen counties. A total of 58.8 million reads were obtained, which were reduced to 57.2 million reads after trimming (Additional file 2: Table S1). After de-novo assembly of each individual sample, 1.95 million contigs were generated. After trimming, on average, each sample had 0.9 million reads that assembled in to 30,004 contigs with an average length of $340 \mathrm{bp}$ (Additional file 2: Table S1). These contigs were used to determine the viruses present in using BlastN against the Plant Virus Genome Database and NCBI "nr" databases. Results clearly indicated the presence of four main viruses: Maize chlorotic mottle virus (MCMV), Sugarcane mosaic virus (SCMV), Maize streak virus (MSV) and Maize Yellow Dwarf virus-RMV (MYDV-RMV) (Fig. 1c). Hubei Potylike virus 1, Barley virus G, Scallion mosaic virus and Johnson grass mosaic virus (JGMV) were detected in a smaller number of samples (Fig. 1d).

\section{Sequence depth and coverage of viruses identified}

Our de-novo assembled single contigs were either short, similar or longer than the reference genomes (Additional file 3: Figure S2). Most of the gaps mapped to the 5' and 3' UTR. Contigs were selected for further analysis based on sequence length and alignment size ( $\geq 80 \%$ of the genome). Alignment size was calculated by subtracting the start from the end of the match using coordinates of the reference genome. In most cases, the alignment size was shorter than the contig size (Additional file 4: Table S2). The polarity of each contig was determined with respect to the reference genome. Graphical alignments for all samples and coverage maps were made for MCMV (Fig. 2), SCMV (Fig. 3), MSV (Fig. 5) and MYDVRMV (Fig. 6). For one representative sample per virus, 
a MCMV genome and contig alignment
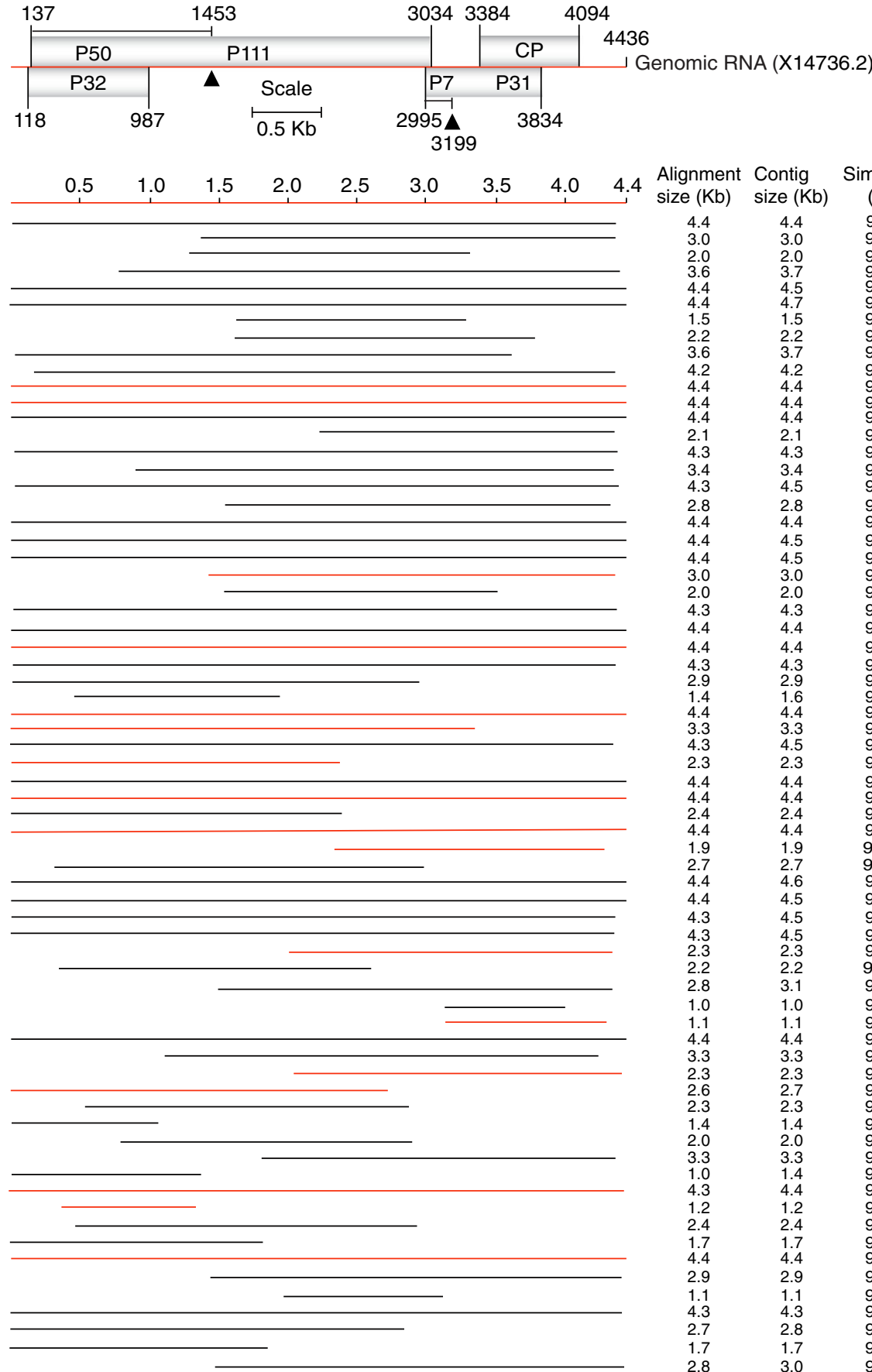

Alignment Contig Sim

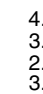

4.
3.
2.
3.

Sample County

Contig

(symptoms)

polarity 
(See figure on previous page.)

Fig. 2 Maize chlorotic mottle virus (MCMV) genome organization and alignment of de novo-assembled contigs. Symptomatic (S) and asymptomatic (A) maize, cultivated $\left(^{*}\right)$ or wild $\left(^{* *}\right)$ sorghum, or napier grass $\left(^{* *}\right)$ were sampled. The county of origin is indicated after the sample number and symptoms. a MCMV genome organization. Coordinates are based on reference sequence number X14736.2. Open reading frames are represented by cylinders. Genomic RNA is represented by a solid line. Arrow heads mark the leaking termination codon in p50 and in p7. Red and black lines, to scale, represent contigs of positive or negative polarity, respectively, aligned to the reference. For every sample categorized as infected the longest contig is shown. Shorter, redundant contigs were not illustrated. Contig size, alignment size, and similarity (\%) are indicated. b Genome coverage after reference based assembly using Bowtie v2 for one representative sample. Sequence depth is indicated on the left. GC content is color coded

coverage and sequence depth at each nucleotide position were obtained. Sequence depth (reads per nt) for MCMV (Fig. 2b), SCMV (Fig. 3b), MSV (Fig. 5b) and MYDV-RMV (Fig. 6b) was at least 150, 200, 2000 and 150 reads, respectively.

Collectively, these results provide a clear identification with high similarity, coverage and depth for four main viruses: MCMV, SCMV, MSV and MYDV-RMV.

\section{Virus prevalence in Kenya and similarity to reference genomes}

MCMV was the most prevalent virus in maize growing regions in Kenya. It was detected in all the 68 samples (Figs. 1b-c and 2a). De-novo assembled contigs ranged from 0.5 to $4.5 \mathrm{~kb}$ (Fig. 2a and Additional file 3: Figure S2) with > 96\% similarity to the Kansas isolate (X14736.2) used as reference (Fig. 2a). Single contigs nearly covering the complete genome were obtained from 30 samples (Fig. 2a and Additional file 3: Figure S2). Respect to the reference genome, these contigs, lacked 2 to $297 \mathrm{nt}$ at the 5 ' end and/or 18 to 213 at the 3 ' end.

SCMV was the second most prevalent virus in maize growing regions of Kenya (Fig. 1b-c). SCMV was present in 60/68 samples, contigs varied from 0.2 to $9.6 \mathrm{~kb}$ (Fig. 3a and Additional file 3: Figure S2) and had 77 to $95 \%$ similarity to the Ohio isolate (JX188385.1) used as (JX188385. 1) (Fig. 3a). Single contigs close in size to the complete genome were obtained for twenty samples (Fig. 3a). These were 1 to $18 \mathrm{nt}$ shorter at the $5^{\prime}$ end and/or 9 to $54 \mathrm{nt}$ shorter at the 3' end. Five contigs were longer than the reference genome (Fig. 3a and Additional file 3: Figure S2) , and had 16 to 222 extra nt at the 5' end and /or 1 to 129 extra nt at the 3' end. A single nucleotide polymorphism analysis (SNP, see below) identified a variable area at the border between NIb and the coat protein (Fig. 4).

MSV was the third most abundant virus in maize growing regions of Kenya (Fig. 1b-c).

MSV was present in 52/68 samples, contigs varied from 0.2 to $2.6 \mathrm{~kb}$ (Fig. 5a and Additional file 3: Figure S2) and similarity to the reference genome (AF329878.1) was $>97 \%$ (Fig. 5a). Single contigs from eight individual samples were almost complete genomes. Two single contigs from two individual samples were longer than the reference genome (Additional file 3: Figure S2). Both had duplicated sequences at the 5' end.
MYDV-RMV was the fourth most abundant virus in maize growing regions of Kenya (Fig. 1b-c). MYDV-RMV was present in 40/68 samples with contigs varying from 0.2 to $5.6 \mathrm{~kb}$ (Fig. 6a and Additional file 3: Figure S2) and > 96\% similarity to the reference genome (MF974579.2) (Fig. 6a). Single contigs close to complete genome were obtained for five samples (Additional file 3: Figure S2). These contigs were 12 to $25 \mathrm{nt}$ shorter at the $5^{\prime}$ end and/or 24 to $112 \mathrm{nt}$ shorter than the reference genome at the 3 ' end.

In addition to single contigs near genome length, for all four viruses described above, additional shorter overlapping contigs (Additional file 3: Figure S2) of opposite polarity were obtained (Additional file 4: Table S2) and used to generate genome length consensus sequences.

\section{Geographic distribution and profile of virus infections in maize}

MCMV was detected in all the 68 samples (Figs. $1 \mathrm{~b}$ and $2 \mathrm{a}$ ) and including maize, sorghum and napier grass, and in all sixteen counties sampled. MCMV was detected in combination with one, two, three, or four other viruses in the 67 samples (Figs. 1b-c and 2a). Thirty of the 68 samples analyzed, included six samples from asymptomatic maize plants, and three sorghum samples, had a combination of four viruses: MCMV, SCMV, MSV and MYDVRMV (Fig. 1c). In thirteen of the sixteen counties included in this study, at least one sample was detected containing all four viruses (Fig. 1b-c). In the three sorghum samples, MCMV was detected in combination with SCMV, MSV and MYDV-RMV (Fig. 1c). In the napier grass sample MCMV was detected alone. Interestingly, sorghum and napier grass plants showed no symptoms of virus infection at sampling (Fig. 1a).

The second most prevalent virus, SCMV, was found in 60 of the 68 samples. In all cases, SCMV was present in combination with MCMV, MSV and MYDV-RMV (Fig. 1c). MSV and MYDV-RMV were found in 52 and 40 samples, respectively. SCMV, MSV and MYDV-RMV were detected in all cases in combination with at least one other virus (Fig. 1c). SCMV and MSV were present in all sixteen counties, while MYDV-RMV was present in thirteen of the sixteen counties sampled.

These results show that MCMV, SCMV, MSV and MYDV-RMV are widely distributed across maize growing counties in Kenya (Fig. 1b). 


\section{SCMV genome and contig alignment}

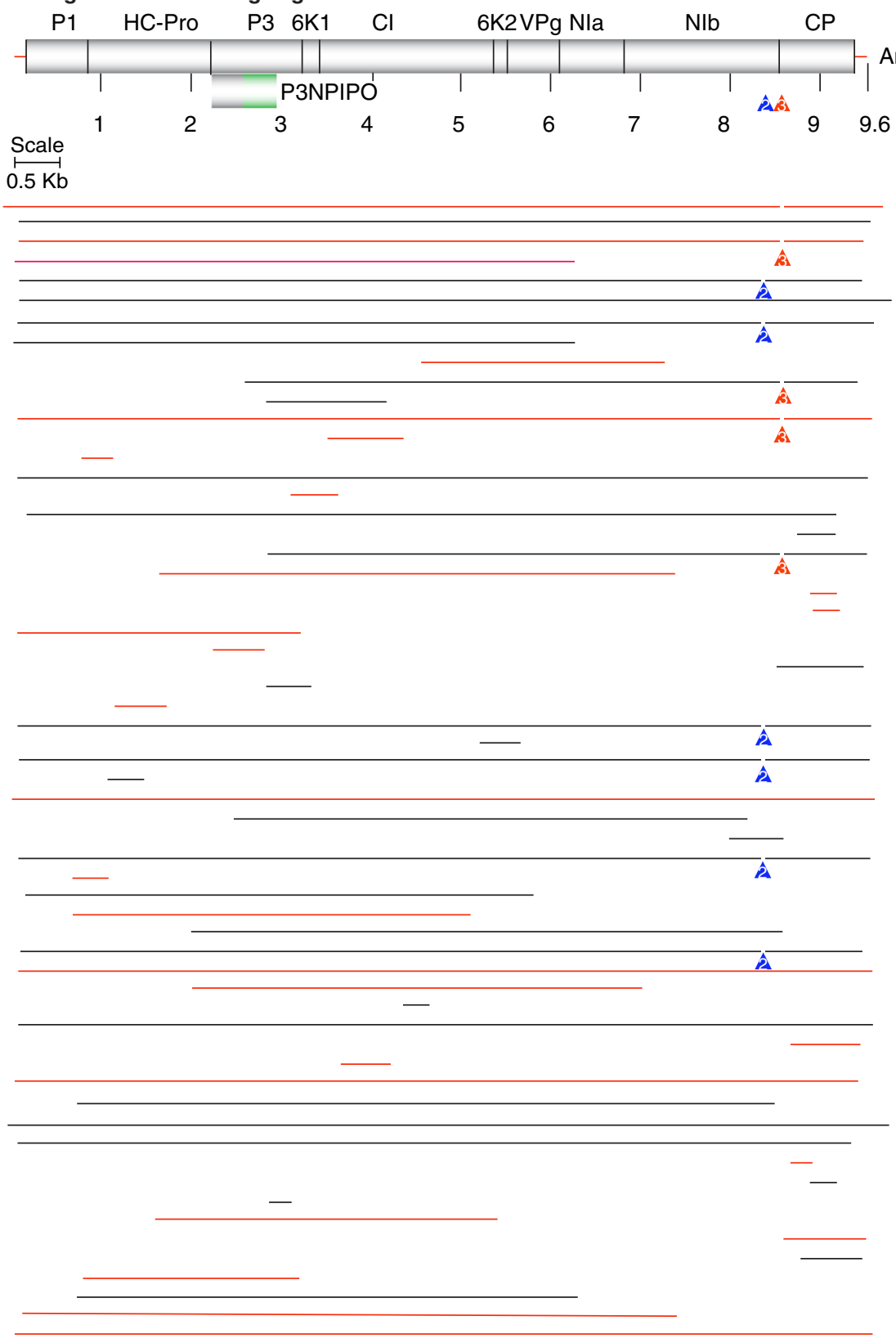

An Genomic RNA (JX188385.1)

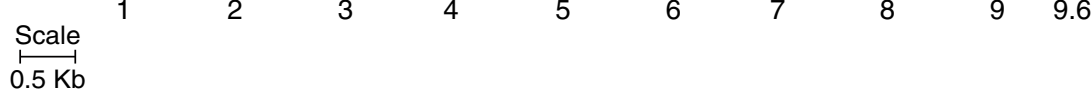

Alignment Contig Similarity Sample

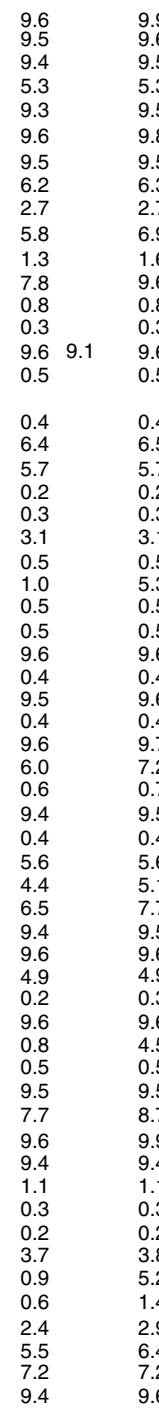

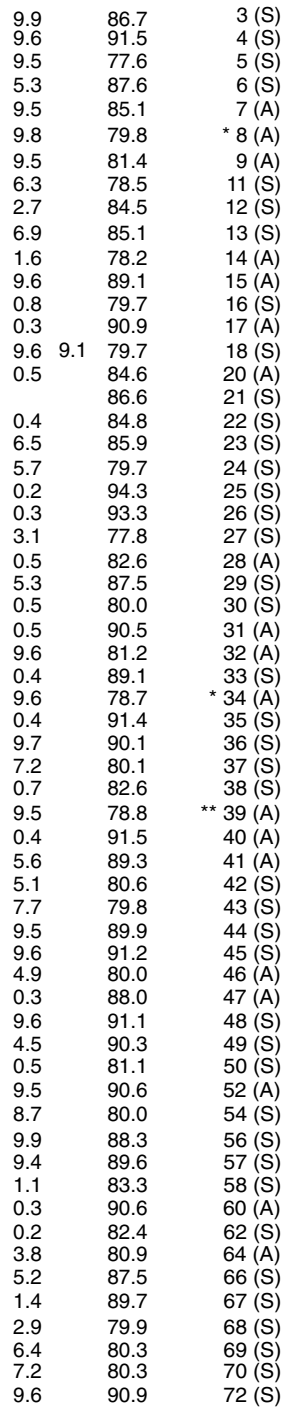

\section{b SCMV coverage}

$0-$ 1 verage

$1630-$

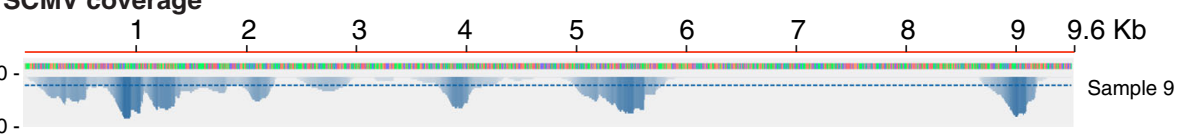

Fig. 3 Sugarcane mosaic virus (SCMV) genome organization and mapping of de novo-assembled contigs. Labels are as in Fig. 2. a SCMV genome and polyprotein organization. Mature proteins are represented by cylinders. Coordinates are based on the Ohio isolate used as reference (JX188385.1). Every sample categorized as infected contributed one representative contig. A variable area was detected between nt 8500 and 8650. Colored arrowheads represent the location of two conserved deletions in the polyprotein coding sequence. A number 2 (group G2) indicates a $39 \mathrm{nt}$ deletion (8487 to 8525) that resulted in an in-frame deletion of 13 amino acids at the C terminus of Nlb. A number 3 (group G3) indicates a $45 \mathrm{nt}$ deletion between nt 8487 to 8676 that resulted in a 15-amino acid deletion. In samples not marked (group G1), variation was observed without insertions or deletions. $\mathbf{b}$ Genome coverage after reference based assembly using Bowtie v2 for one representative sample 


\section{a SCMV single nucleotide polymorphism}
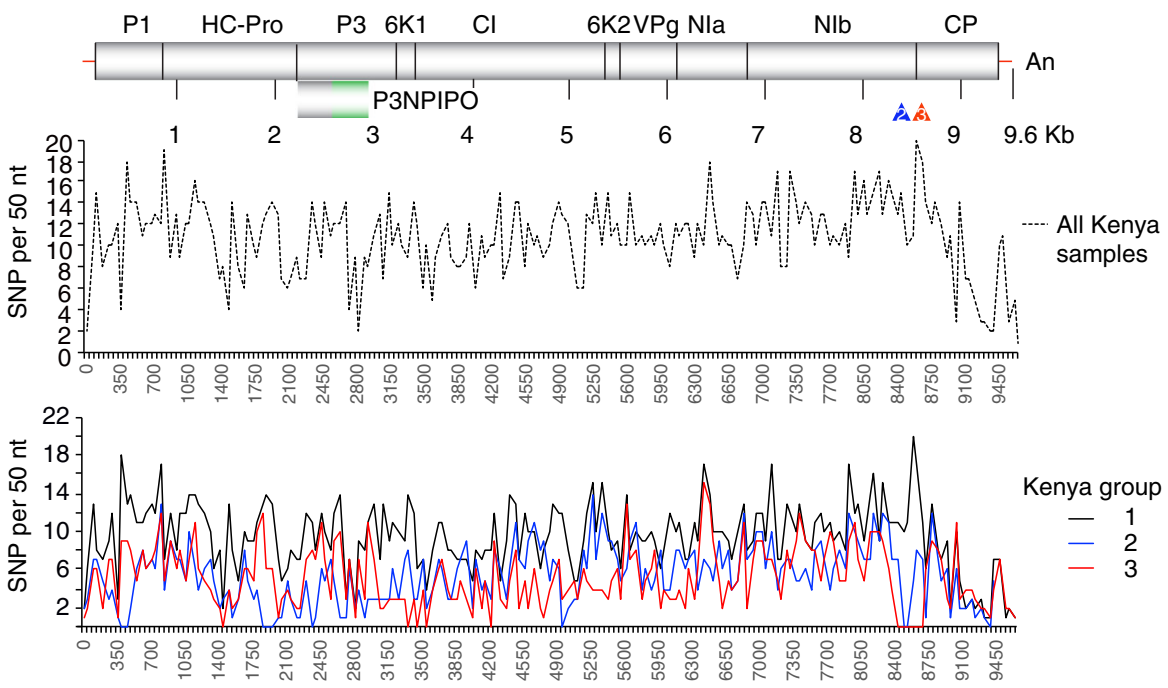

\section{b SCMV partial polyprotein sequence alignment}

\begin{tabular}{|c|c|c|c|c|}
\hline JX188385.1 & & 2710 & ALRNLYLGTGIKEEEIEKYFKQFIKDLPGY IEDYNEDVFHQSGTVDAGTQGGSGSQGTTP & 2769 \\
\hline Kenya group & 1 & & ALRNLYLGTGI KEEEIEIYFKQFVKDLPGY IEDYNEEVIHQSGTVDAGAQGGSGSQGTTP & \\
\hline KF744391.1 & (Rwanda) & & ALRNLYLGTGIKEEEIEIYFKQFVKDLPGY IEDYNEEVIHQSGTVDAGAQGGSGSQGTTP & \\
\hline KF744392.1 & (Rwanda) & & ALRNLYLGTGI KEEEIEKYFKQFVKDLPGYIEDYNEEVIHQSGTVDAGAQGGGGNQGTTP & \\
\hline KP860936.1 & (Ethiopia) & & ALRNLYLGTGI KEEEIEKYFKQFVKDLPGYIEDYNEEVIHQSGTVDAGAQGGSGSQGTTP & \\
\hline KP772216.1 & (Ethiopia) & & ALRNLYLGTGI KEEEIEKYFKQFVKDLPGY I EDYNEEVIHQSGTVDAGAQGGSGSQGTTP & \\
\hline GU474635.1 & (Mexico) & & ALRNLYLGTGI KEEEIEKYFKQFAKDLPGY IEDYNEDVFHQSGSVDAGVQGGSGNOGTTP & \\
\hline Kenya group & 2 & & ALRNLYLGTGI KEEEIEKYFKQFVKDLPGYIEDYNEEVIHQSGTVDAGAQGGGGNQGTTP & \\
\hline KP860935.1 & (Ethiopia) & & ALRNLYLGTGIKEEEIEKYFKQFVKDLPGY IEDYNEDVIHQSGTVDAGAQGGSGNQGTTP & \\
\hline Kenya group & 3 & & ALRNLYLGTGIKEEEIEKYFRQFVKDLPGYVEDYNEEVIHQSGQVDAGRQGGSGAQGGTP & \\
\hline JX047391.1 & (China) & & ALRNLYLGTSI KEEEIEKYFRQFVKDLPGYVEDYNEEVIHQSGQVDAGRQGGSGAQGGTP & \\
\hline JX286708.1 & (Kenya) & & SGQVDARQGGSGAQGGTP & \\
\hline & & & $\begin{array}{l}* * * * * * * * * . * * * * * \\
\text { Coat protein }\end{array}$ & \\
\hline JX188385.1 & (Ohio, USA) & 2770 & PATGSGAKPATSGAGSGSSTGAGTGVTGSOAGAGGSAGTGSGATGGOSGSGSGTGQINTG & 2828 \\
\hline Kenya group & & & PATGSGSKPAASGAGSGSGTGTGTGATGGQTGNGSGAGTGSGATGGQSGSGSGTGQTGTG & \\
\hline KF744391.1 & (Rwanda) & & PATGSGSKPATSGAGSGSGTGTGTGATGGQTGTGSGAGTGSGATGGQSGSGSGTGQTGTG & \\
\hline KF744392.1 & (Rwanda) & & PATGGGAKPANSGAGSGSGTGTGTGATGGQTGTGSGAGAGSGATGGQSGSGSGTGQTGTG & \\
\hline KP860936.1 & (Ethiopia) & & PATGSGARPATSGAGSGSGTGTGAGATGGQTGAGSGAGTGSGAAGGQSGSGSGAGQTGTG & \\
\hline KP772216.1 & (Ethiopia) & & PATGGGARPAASGAGSGSGTGTGAGATGGQTGAGSGAGTGSGATGGQSGSGSGAGQTGTG & \\
\hline GU474635.1 & (Mexico) & & PATGSGAKPATSGAGSGSGTGTGTGVTGGQAGASSGAGTGSGATGGQSGSGSGTGQNGTG & \\
\hline Kenya group & 2 & & PATGNG- & \\
\hline KP860935.1 & (Ethiopia) & & PATGGG- & \\
\hline Kenya group & 3 & & PAGSGGTGSGTQGNGGQTGS - . . - - QGSSGQQGSGGGTGQGAAGN - . . . . - - NGGGQ & \\
\hline JX047391.1 & (China) & & - - - QGSGGQQGSGGGTGQGAAGN - . & \\
\hline JX286708.1 & (Kenya) & & PAGSGGTGSTQGNGGQTGS - . - . - Q QGSGGQQGSGGGTGQGAAGN- & \\
\hline & & & $\star^{*}, \quad \ldots \quad:{ }^{*} * *:$. & \\
\hline JX188385.1 & (Ohio, USA) & 2829 & SAGTSATGGORDRDVDAGTTGKISVPKLKAMSKKMRLPKAKGKDVLHLDFLLTYKPOOOD & 2888 \\
\hline Kenya group & & & SAGTGSTGGQRDKDVDAGTTGNITVPKLKAMSKKMRLPKAKGKDVLHLDFLLTYKPQQQD & \\
\hline KF744391.1 & (Rwanda) & & SAGTGATGGQRDKDVDAGTTGKISVPKLKAMSKKMRLPKAKGKDVLHLDFLLTYKPQQQD & \\
\hline KF744392.1 & (Rwanda) & & SAGTGATGGQRDKDVDAGTTGKISVPKLKAMSKKMRLPKAKGKDVLHLDFLLTYKPQQQD & \\
\hline KP860936.1 & (Ethiopia) & & SAGTGATGGQRDKDVDAGTTGKISVPKLKAMSKKMRLPKAKGKDVLHLDFLLTYKPQQQD & \\
\hline KP772216.1 & (Ethiopia) & & SAGTGATGGQRDKDVDAGTTGKISVPKLKAMSKKMRLPKAKGKDVLHLDFLLTYKPQQQD & \\
\hline GU474635.1 & (Mexico) & & SAGTSATGSQRDRDVDAGSTGKISVPKLKAMSKKMRLPKAKGKDVLHLDFLLTYKPQQQD & \\
\hline Kenya group & 2 & & SAGTGATGGQRDKDVDAGTTGKISVPKLKAMSKKMRLPKAKGKDVLHLDFLLTYKPQQQD & \\
\hline KP860935.1 & (Ethiopia) & & SAGTGATGGQRDKDVDAGTTGKISVPKLKAMSKKMRLPKAKGKDVLHLDFLLTYKPQQQD & \\
\hline Kenya group & & & TGGSSGTSGQRDKDVDAGSAGKISVPKLKAMSKKMRLPKAKGKDVLHLDFLLTYKPQQQD & \\
\hline JX047391.1 & (China) & & TGGSSGTAGQRDKDVDAGSAGKISVPKLKAMSKKMRLPKAKGKDVLHLDFLLTYKPQQQD & \\
\hline $\mathrm{JX} 286708.1$ & (Kenya) & & TGGSSGTAGQRDKDVDAGSAGKISVPKLKAMSKKMRLPKAKGKDVLHLDFLLTYKPQQQD & \\
\hline
\end{tabular}

Fig. 4 SCMV genetic variation. Coordinates are based on the Ohio isolate (JX188385.1). a SNP distribution across the SCMV genome for all samples and by genetic group. b Partial polyprotein sequence alignment, using MAFFT, of Kenya samples in variation groups 1, 2 and 3, and isolates from other parts of the world relative to the Ohio isolate. The coat protein detected in the original description of maize lethal necrosis in Kenya was used for comparison (JX286708.1) [6]. Nlb and coat protein coding sequences are color coded blue and red, respectively. Green background indicates variation

\section{Other viruses infecting maize}

Four potyviruses and one polerovirus were detected in a smaller number of samples (Fig. 1d). Hubei Poty-like virus 1 (19 samples), Scallion mosaic virus (7 samples), JGMV (5 samples), and Iranian JGMV (2 samples) are potyviruses. Barley virus $G$ (11 samples) is a polerovirus.
The Hubei Poty-like virus 1 reference genome ( $\mathrm{NC}_{-}$ 032912.1) is $9356 \mathrm{nt}$ long. The longest contig we obtained was $9323 \mathrm{nt}$ long and was $77.3 \%$ similar to the reference (sample 48 ). The highest similarity $(87.3 \%)$ to the reference genome was obtained for a 206-bp contig (sample 68). The Scallion mosaic virus reference genome 


\section{a MSV genome and conting alignment}

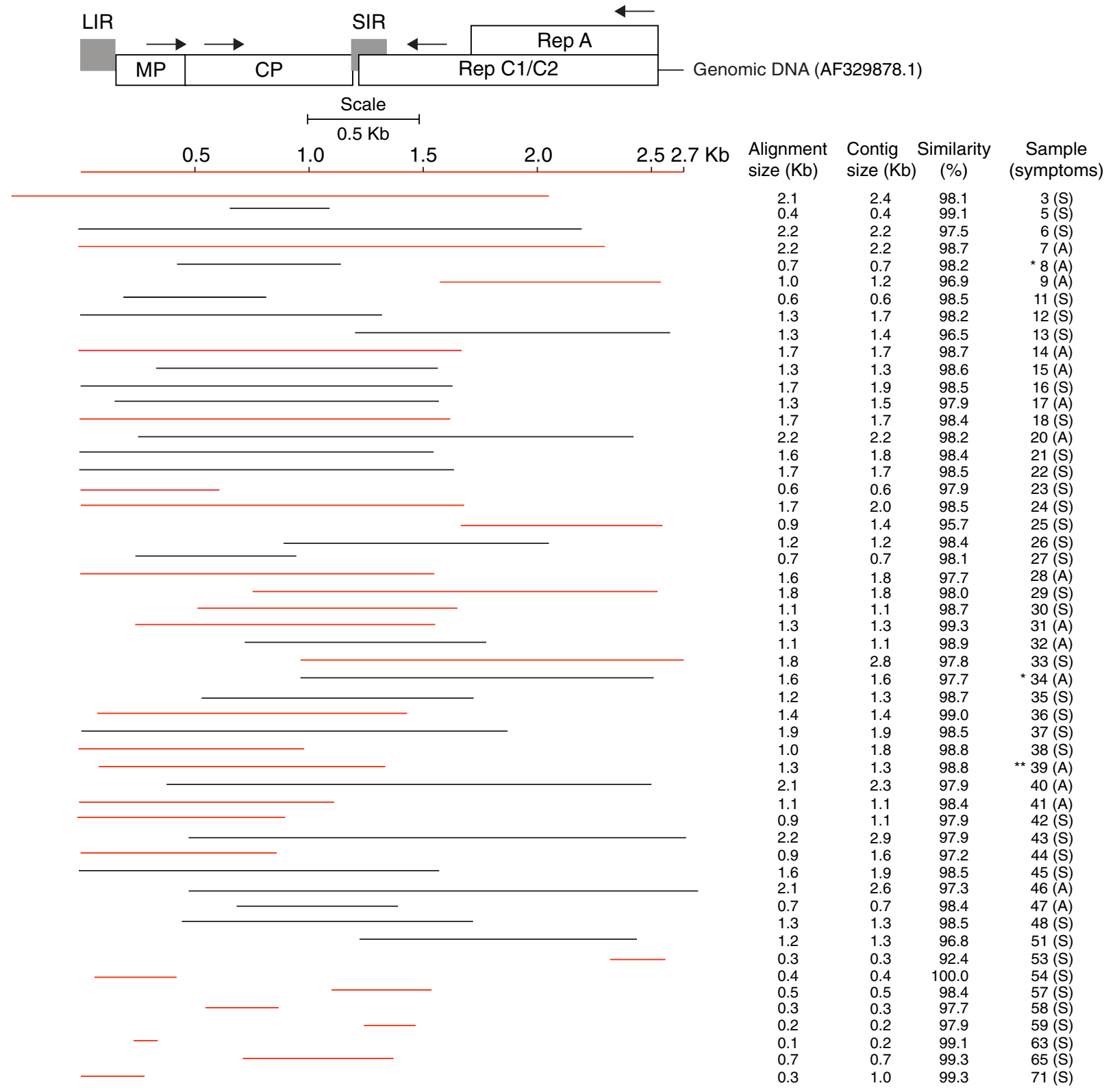

\section{b MSV coverage}
0.5
1.0
1.5
2.0
$2.52 .7 \mathrm{~Kb}$

0

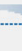

6000 -

Fig. 5 Maize streak virus (MSV) genome organization and alignment of de novo-assembled contigs. Labels are as in Fig. 2. a MSV genome organization. Open reading frames are represented by cylinders. Genomic DNA is represented by a solid line. Coordinates are based on reference sequence number AF329878.1. Large (LIR) and small (SIR) are represented by shaded boxes. Direction of transcription is indicated by arrows. Every sample categorized as infected contributed one representative contig. Shorter, redundant contigs were not illustrated. b Genome coverage after reference based assembly using Bowtie 22 for one representative sample 


\section{a MYDV-RMV genome and contig alignment}
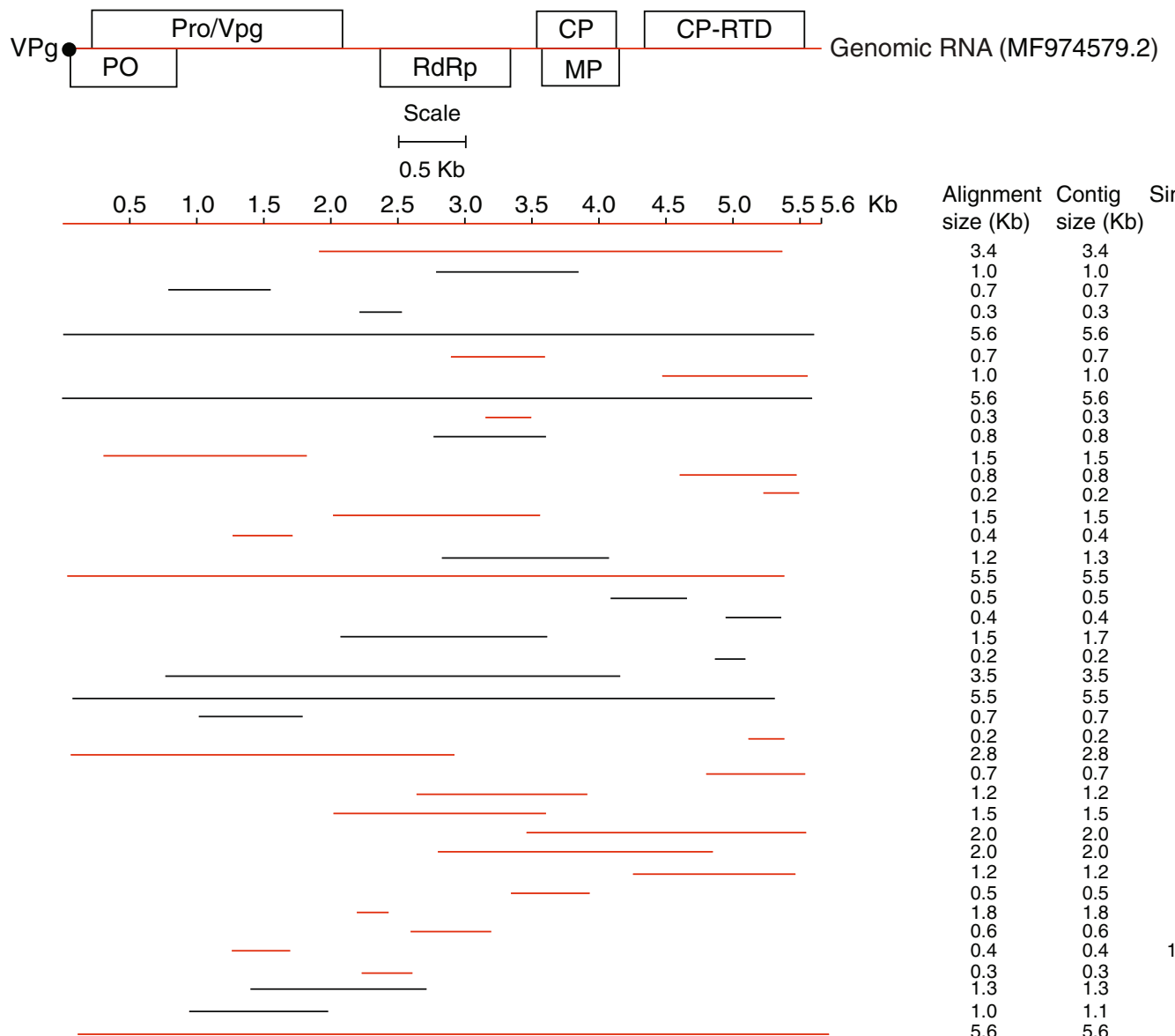

$\begin{array}{ccr}\text { Alignment } & \text { Contig } & \text { Similarity } \\ \text { size }(\mathrm{Kb}) & \text { size }(\mathrm{Kb}) & (\%) \\ 3.4 & 3.4 & 99.3 \\ 1.0 & 1.0 & 99.6 \\ 0.7 & 0.7 & 98.3 \\ 0.3 & 0.3 & 99.0 \\ 5.6 & 5.6 & 99.1 \\ 0.7 & 0.7 & 99.0 \\ 1.0 & 1.0 & 98.8 \\ 5.6 & 5.6 & 98.6 \\ 0.3 & 0.3 & 99.7 \\ 0.8 & 0.8 & 99.8 \\ 1.5 & 1.5 & 99.4 \\ 0.8 & 0.8 & 98.2 \\ 0.2 & 0.2 & 98.5 \\ 1.5 & 1.5 & 99.4 \\ 0.4 & 0.4 & 99.7 \\ 1.2 & 1.3 & 98.9 \\ 5.5 & 5.5 & 98.3 \\ 0.5 & 0.5 & 97.0 \\ 0.4 & 0.4 & 98.5 \\ 1.5 & 1.7 & 99.4 \\ 0.2 & 0.2 & 99.1 \\ 3.5 & 3.5 & 98.5 \\ 5.5 & 5.5 & 99.3 \\ 0.7 & 0.7 & 99.7 \\ 0.2 & 0.2 & 97.0 \\ 2.8 & 2.8 & 98.6 \\ 0.7 & 0.7 & 98.6 \\ 1.2 & 1.2 & 99.2 \\ 1.5 & 1.5 & 98.9 \\ 2.0 & 2.0 & 98.7 \\ 2.0 & 2.0 & 99.7 \\ 1.2 & 1.2 & 99.7 \\ 0.5 & 0.5 & 99.8 \\ 1.8 & 1.8 & 99.5 \\ 0.6 & 0.6 & 99.5 \\ 0.4 & 0.4 & 100.0 \\ 0.3 & 0.3 & 99.4 \\ 1.3 & 1.3 & 98.2 \\ 1.0 & 1.1 & 99.6 \\ 5.6 & 5.6 & 99.6\end{array}$

Sample (symptoms)

3 (S)

4 (S)

5 (S)

7 (A)

* 8 (A)

9 (A)

15 (A)

16 (S)

22 (S)

23 (S)

24 (S)

25 (S)

26 (S)

29 (S)

30 (S)

31 (A)

33 (S)

34 (A)

36 (S)

37 (S)

$38(\mathrm{~S})$

39 (A)

\section{b MYDV-RMV coverage}

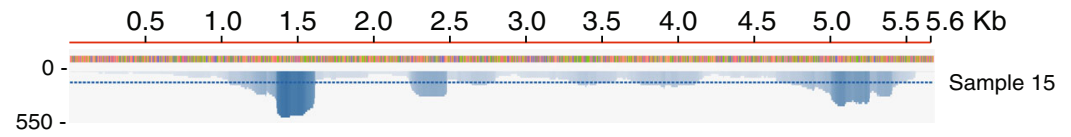

Fig. 6 Maize yellow dwarf virus (MYDV-RMV) genome organization and alignment of de novo-assembled non-overlapping contigs from symptomatic (S) and asymptomatic (A) maize, cultivated $\left(^{*}\right)$ or wild $\left(^{* *}\right)$ sorghum. Labels are as in Fig. 2. a MYDV-RMV genome organization and gene expression. Open reading frames are represented by cylinders. Genomic RNA is represented by a solid line. Coordinates are based on reference sequence number MF974579.2. Every sample categorized as infected contributed one representative contig. Shorter, redundant contigs were not illustrated. b Genome coverage after reference based assembly using Bowtie v2 for one representative sample

(NC_003399.1) is 9324 nt long. The longest contig we obtained was $962 \mathrm{nt}$ long and was $80.0 \%$ similar to the reference (sample 20$)$. The highest similarity $(89.3 \%)$ to reference genome was obtained for a 271-bp contig (sample 68). The JGMV reference genome (NC_003606. 1) is 9779 nt long. The longest contig we obtained was $1535 \mathrm{nt}$ long and was $75.0 \%$ similar to the reference (sample 46). The highest similarity (85.6\%) to reference genome was obtained for a 967-bp contig (sample 30).

Collectively, these results show that Hubei Poty-like virus 1, Scallion mosaic virus,
$J G M V$, Iranian JGMV, and Barley virus $G$ are part of the virus complex infecting maize in Kenya and their genetic composition is distant from isolates described before (Fig. 1d).

\section{Low genetic diversity of maize chlorotic mottle virus in Kenya}

Thirty contigs from this study (Additional file 5) were used for a phylogenetic analysis that included 16 sequences from GenBank representing MCMV world wide variation [37]. MCMV sequences from Kenya were at 
least 96\% similar to the Kansas isolate (X14736.2) used as reference (Fig. 2a). In agreement with world wide variation [37], our results showed a clear distribution of MCMV isolates in different clades based on their geographic origin (Fig. 7a). Kenya samples described here clustered in the clade containing isolates from East Africa, close to isolates from China and away from isolates from the American continent (Fig. 7a). Within our Kenya samples, there was no correlation with the county or host of origin. One sample (number 16) lacking $15 \mathrm{nt}$ and $205 \mathrm{nt}$ at the $5^{\prime}$ end and $3^{\prime}$ end, respectively, showed the most distance from the African cluster (Fig. 7a). Results described here and before [37] show that there is low genetic variation in the MCMV population in Kenya.

\section{a MCMV}

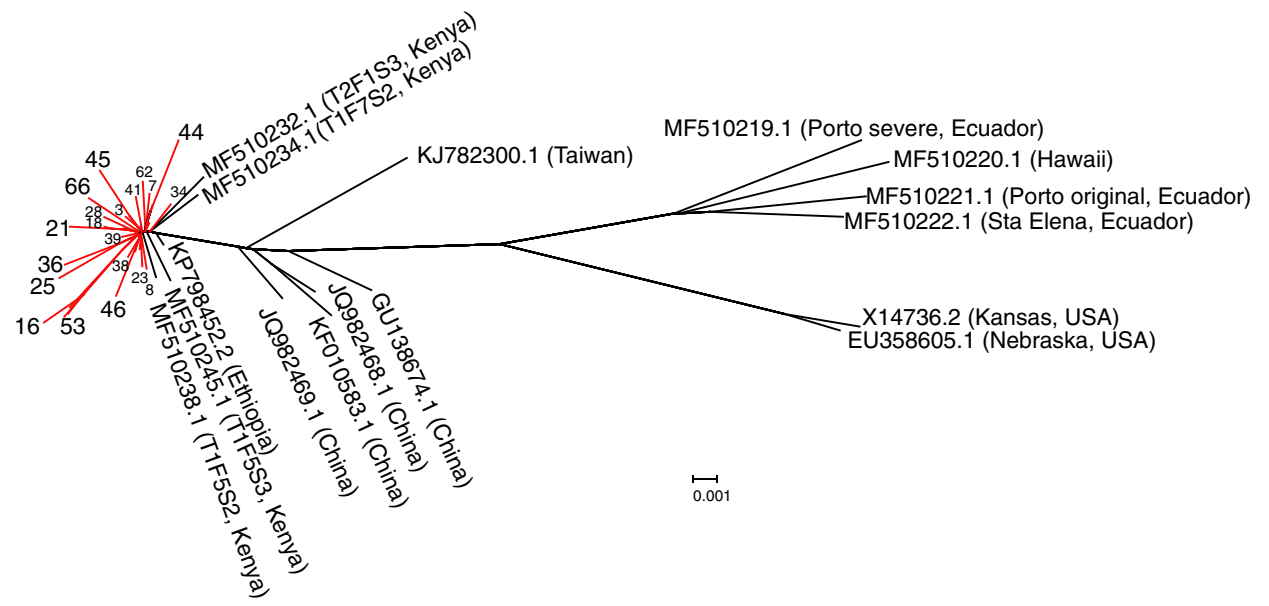

b ScMv

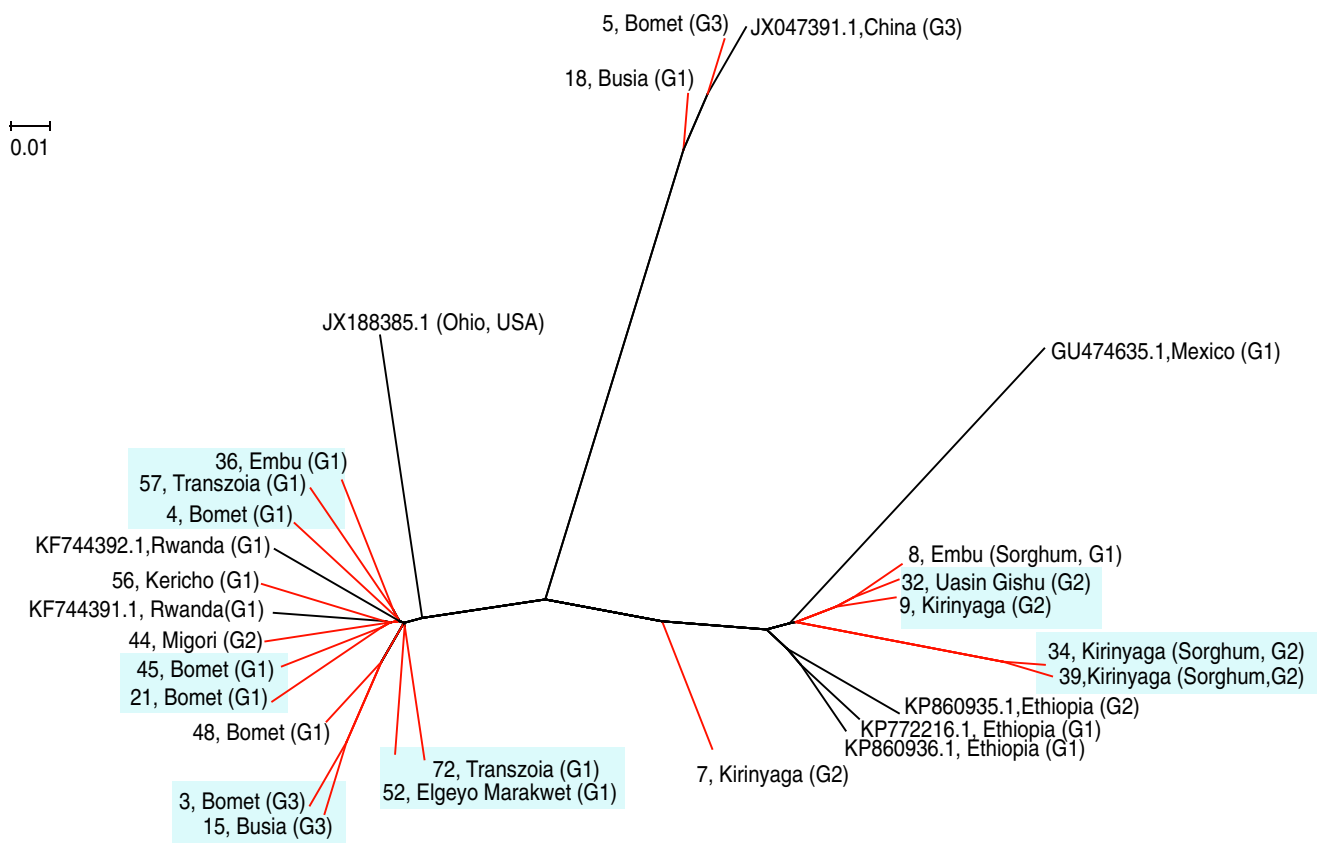

Fig. 7 Phylogeny of MCMV (a) and SCMV (b). Phylogenetic trees were generated using Bayesian inference in Mr. Bayes 3.2. Scale bar represents nucleotide substitution per site. For SCMV, G1, G2 and G3 correspond to genetic variation and groups described in Fig. 4. Kenya samples described in this study are colored in red and identified by a number and the county of origin. Unless indicated otherwise, samples came from maize. Green background indicates clusters formed by Kenya samples 


\section{Genetic variation in Sugarcane mosaic virus}

Twenty SCMV sequences from this study (Additional file 6) and eight complete genomes from GenBank representing different parts of the world were used on a phylogenetic analysis. Previously described isolates from Rwanda, Ohio, China, Mexico, and Ethiopia formed clearly separate clusters (Fig. 7b). Samples described here were distributed in six different clusters containing at least two members. Six other samples were placed individually near clusters formed by Kenya samples or isolates from other parts of the world. Consistent with variation in similarity (77 to 94\%) to the Ohio isolate (JX188385.1) (Fig. 3a), this result, suggests that there is genetic variation in the SCMV population in Kenya.

Alignment to the Ohio isolate showed that out of the twenty near genome length contigs, eleven had a gap that mapped to the border between NIb and the coat protein (Fig. 3a). To understand this variation, a single nucleotide polymorphism analysis (SNP) was carried out using the twenty SCMV contigs near genome length used in the phylogenetic analysis (Additional file 6). SNP were estimated at a $50 \mathrm{nt}$ interval. Although there was additional variation across the genome, the most variation mapped to nt 8500 to 8650 which corresponds to the border between NIb and the coat protein (Fig. 4a) and include the gaps observed in the alignment to the Ohio isolate (Fig. 3a). Nucleotide (Additional file 7: Figure S3) and amino acid sequence alignment of the NIb and coat protein separated our Kenya samples into three distinct groups (Fig. 4b). Group one (samples 4, 8 , $18,21,36,45,48,52,56,57$ and 72 ) was the most frequent, and no nucleotide insertions or deletions were observed (Additional file 7: Figure S3). However, there were nucleotide and amino acid substitutions at the $\mathrm{C}$ terminus of NIb and at the $\mathrm{N}$ terminus of the coat protein (Fig. 4b). Group two (samples 7, 9, 32, 34, 39 and 44) had a 39-nt deletion (8487 to 8525) (Additional file 7 : Figure S3) that resulted in an in-frame deletion of 13amino acids at the $\mathrm{C}$ terminus of NIb (Fig. 4b). Group three (samples 3, 5, and 15) had low similarity and a 45nt deletion between nt 8487 to 8676 (respect to the reference) (Additional file 7: Figure S3) that resulted in a 15-amino acid deletion. An SNP analysis for samples within each group clearly distinguished the three groups described above and showed that most of the variation maps to nt 8500 to 8650 . At that interval, groups 2 and 3 harbor a deletion. However, additional variation occurs across the rest of the genome (Fig. 4a, lower panel). Interestingly, in this analysis, the least variation was observed at the PIPO coding sequence (Fig. 4a, middle panel). PIPO is a highly conserved protein in potyviruses with an essential role in virus movement [40].

To further characterize genetic variation in SCMV from Kenya, the polyprotein was obtained for the consensus sequence of each group and aligned to the polyprotein for isolates representing several parts of the world. No complete genome has been described for SCMV from Kenya to date. The coat protein sequenced in the original description of maize lethal necrosis in Kenya was used for comparison (JX286708.1) [6]. Consistent with the SNP and nucleotide sequence alignment, variation in the SCMV polyprotein formed three groups. Respect to the Ohio isolate, group one has several amino acid substitutions at the $\mathrm{C}$ terminus of NIb and at the $\mathrm{N}$ terminus of the coat protein (Fig. 4b). Similar variation was observed for two isolates from Rwanda, two from Ethiopia and one from Mexico. In addition to amino acid substitutions similar to those in group 1, group two has a deletion of 13-amino acids at the $C$ terminus of NIb. The same deletion is present in one isolate from Ethiopia (Fig. 4b). In addition to amino acid substitutions similar to those in group 1, group three has a 15 -amino acid deletion. Six amino acids mapped to the $\mathrm{C}$ terminus of $\mathrm{NIb}$ and nine mapped to the $\mathrm{N}$ terminus of the coat protein (Fig. 4b). This deletion is present in one isolate from China and in the isolate from the original description of maize lethal necrosis in Kenya (JX286708.1) [6] (Fig. 4b).

In the phylogenetic analysis, samples that cluster together belong to the same group based on variation between NIb and the coat protein (Fig. 7b). However, some samples from the same group were placed away from the cluster (Fig. 7b), suggesting that there is additional variation along the SCMV genome. In support of this observation, the SNP analyses identified other sources of variation in the SCMV genome (Fig. 4a, lower panel).

Samples from the counties of Kirinyaga and Uasin Gishu clustered near isolates from Ethiopia, while samples from Bomet, Migori, Transzonia and Kericho clustered near isolates from Rwanda (Fig. 7b). Thus, there is correlation between geographic location and genetic diversity of SCMV populations in Kenya. However, samples from Busia, and from Embu, were in separate clusters.

Variation described above for SCMV in Kenya is unlikely to be sequencing error, because similar deletions are present in published SCMV isolates and because variation mapped to a common area in all samples analyzed (Fig. 3a). Furthermore, geographic distribution of genetic variation was not random. Of the six samples in group two, four came from the county of Kirinyaga: two from maize (samples 7, 9) and two from sorghum (samples 34 and 39) (Fig. 3a). Of the three samples in group three (samples 3, 5, and 15), two (3 and 5) came from maize samples from the county of Bomet and one from the county of Busia.

Results described above show that SCMV from Kenya exhibits high genetic variation that formed six clusters based on genome sequence. Kenya samples and isolates from other parts of the world can be divided into at least 
three groups based on nucleotide and amino acid sequence at the $\mathrm{C}$ terminus of NIb and $\mathrm{N}$ terminus of the coat protein (Fig. 4b).

\section{Maize streak virus exhibits low genetic variation}

MSV described in this study showed 96 to 100\% similarity to the South African isolate (AF329878.1) used as reference (Fig. 5a). Eight contigs representing almost complete genomes (Additional file 8) and eight from GenBank were used for a phylogenetic analysis. Six of our Kenya contigs clustered near isolates from Uganda, Nigeria, and previously described Kenya isolates (Fig. 8a). Two samples (33 and 44) from Kenya clustered separately near isolates from New Zealand and South African isolates. These and previous results [41] show low genetic variation in the MSV population in Kenya.

\section{Polerovirus complex infecting maize}

Based on five contigs (Additional file 9) from this study and seventeen sequences from GenBank, a phylogenetic tree was obtained for MYDV-RMV. Maize yellow mosaic virus and Maize yellow dwarf virus-RMV2 were included for comparison. Sequences from Kenya obtained in this study were 97 to $100 \%$ similar to (Fig. 6a) and four clustered near the MYDV-RMV reference (MF974579.2), while two clustered near Maize yellow mosaic virus (MaYMV) isolate from Nigeria (Fig. 8b). However, the similarity between MYDV-RMV and MaYMV is $98.67 \%$.

These results and the widespread distribution of MaYMV in Rwanda [21] suggest that in Kenya there is a complex of closely related poleroviruses that include Maize yellow dwarf virus-RMV and Maize yellow mosaic virus, and possibly others, such Barley virus $G$ which was detected in 11 of the 68 samples (Fig. 1d).

\section{a MSV}

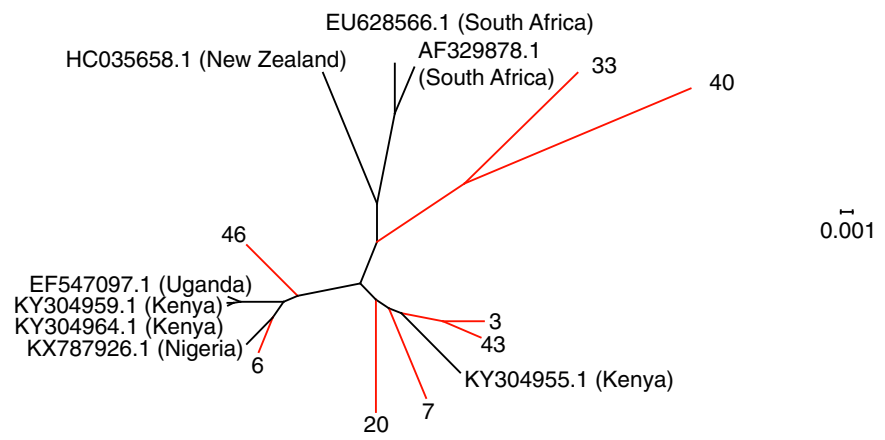

b MYDV-RMV

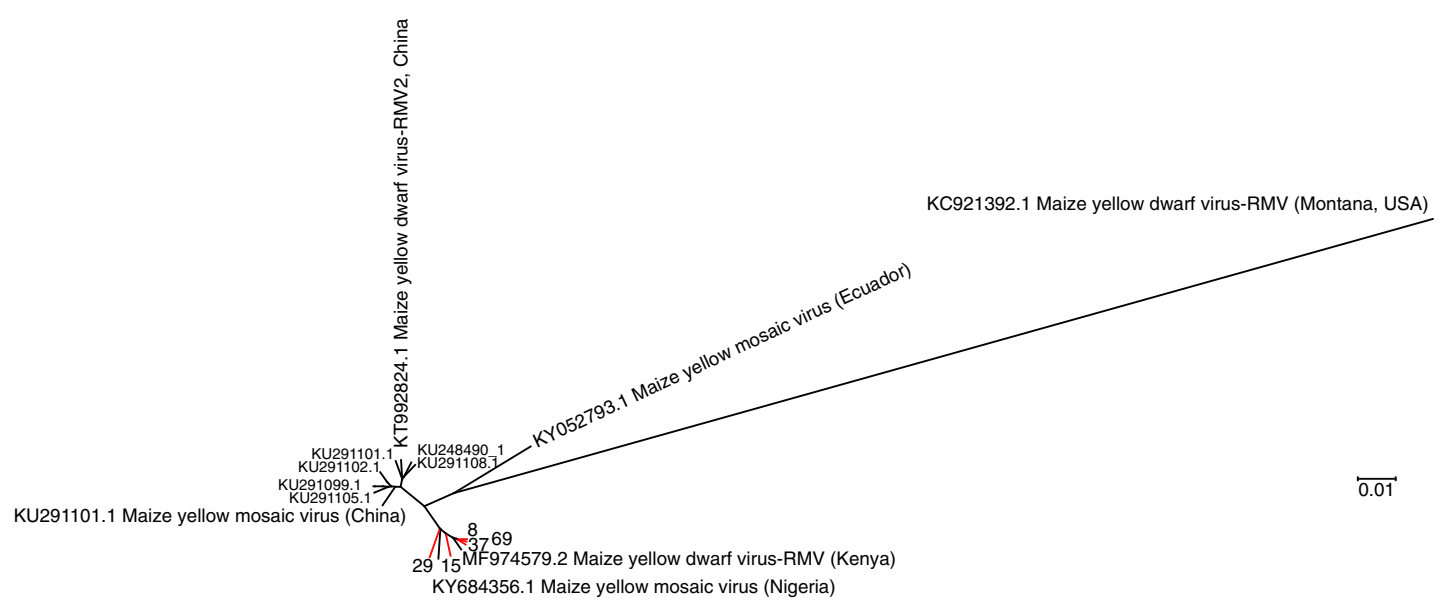

Fig. 8 Phylogeny of MSV (a) and MYDV-RMV (b). Phylogenetic trees were generated using Bayesian inference in Mr. Bayes 3.2. Scale bar represents nucleotide substitution per site. Kenya samples described in this study are colored in red and identified by a number 


\section{Discussion}

Maize lethal necrosis disease is caused by the synergistic co-infection of MCMV and a member of the Potyviridae. Synergism has been confirmed for SCMV [6, 12], WSMV [18], and JGMV [19]. Recently, the polerovirus Maize yellow mosaic virus (MaYMV) was detected in maize plants showing lethal necrosis-like symptoms in Rwanda [21]. In the analysis described here, the polerovirus Maize yellow dwarf virus (MYDV-RMV) was found to be widely distributed in Kenya (Figs. 1b and 6), and the polerovirus Barley virus $G$ was detected in 11 of the 68 samples analyzed (Fig. 1d). MYDV-RMV was always found as part of a complex that included MCMV and SCMV, or MCMV, SCMV and MSV. The wide distribution of poleroviruses infecting maize in Rwanda [21] and in Kenya (Fig. 1b) suggests the possibility of a synergistic interaction between MCMV and a polerovirus to cause maize lethal necrosis, and may contribute to the variation on virus-induced symptoms observed in the field (Fig. 1a).

The molecular mechanisms of viral synergism in maize lethal necrosis remain to be determined. One model is that maize lethal necrosis is mediated by silencing suppressors encoded by the co-infecting viruses. In support of this model, the synergistic interaction between potyviruses and Potato virus $X$ (PVX) and Cucumber mosaic virus (CMV) is mediated by silencing suppression activity of potyviral HC-Pro [42, 43]. Consistent with this model, SCMV and WSMV encode RNA silencing suppressors HC-Pro and P1, respectively [44, 45]. Several, poleroviruses, including MaYMV encode PO, a strong RNA silencing suppressor [46]. These observations are consistent with a role for maize-infecting poleroviruses in maize lethal necrosis.

However, no silencing suppressor has been described for MCMV [47] or MSV (a Mastrevirus) [48]. Interestingly, in Wheat dwarf virus (a Mastrevirus) replication-associated proteins are silencing suppressors [49], which suggest that MSV harbors silencing suppressor proteins. Further investigation is needed to determine the role of silencing suppression, and the contribution of poleroviruses and MSV to maize lethal necrosis.

There is ambiguity with respect to the scientific name given to poleroviruses infecting maize. In 2013, the first species was named Maize yellow dwarf virus (MYDVRMV) [50]. Two different isolates from China were named Maize yellow mosaic virus (MaYMV) [46] and Maize yellow dwarf virus-RMV2 (MYDV-RMV2) [51], while an isolate infecting sugarcane in Nigeria was named Maize yellow mosaic virus (MaYMV) [52], and an isolate infecting maize in Kenya was renamed as Maize yellow dwarf virus-RMV (MF974579.2). Three near genome length polerovirus contigs from maize and one from sorghum described here were most closely related (99\% similarity) to Maize yellow dwarf
virus-RMV (Figs. 6b and 8b). However, one near genome length contig from maize was most closely related to Maize yellow mosaic virus (MaYMV) (Fig. 8b), the most prevalent virus infecting maize in Rwanda [21]. These observations suggest that a complex of closely related poleroviruses infect both maize, sorghum, and possibly other species in East Africa.

In East Africa, ELISA [19, 21, 22] and RT-PCR [9] procedures have provided inconsistent detection of SCMV. Sequencing analysis described here and before [6] show that the SCMV present in Kenya (Figs. 3 and 4) and in Rwanda [9] is distantly related to isolates from other parts of the world (Fig. 7b). Interestingly, our results showed that most of the variation occurs between the $\mathrm{C}$ terminus of NIb and the $\mathrm{N}$ terminus of the coat protein (Figs. 3a and 4). Both nucleotide and amino acid variation was observed in all twenty Kenya samples that provided near complete genome contigs (Fig. 4 and Additional file 7: Figure S3). Based on this variation, Kenya samples, and isolates from other parts of the world, were divided into three groups. Nucleotide substitutions that resulted in several amino acid substitutions in both NIb and the coat protein was the most frequent event (group 1, 11 samples) (Figs. 3a and 4b). However, in the other nine samples, inframe deletions resulted in a 13-amino acid deletion at the C terminus of NIb (group 2, 6 samples) (Fig. 4b), or in a 15-amino acid deletion distributed between the $C$ terminus of $\mathrm{NIb}$ and the $\mathrm{N}$ terminus of the coat protein (group 3, 3 samples) (Fig. 4b).

In members of the Potyviridae, NIb is required for virus replication, while the coat protein participates in virion assembly, cell-to-cell and systemic movement [53]. The effect of amino acid substitutions and deletions at the $\mathrm{C}$ terminus of $\mathrm{NIb}$ and at the $\mathrm{N}$ terminus of the coat protein on virus pathogenicity remain to be determined. Presence of these deletions in SCMV isolates from other parts of the world suggest that viruses harboring these deletions are pathogenic. Consistent with this hypothesis, in Wheat streak virus (Family Potyviridae, genus Tritimovirus), a genetic analysis using an infectious clone showed that deletions at the $\mathrm{N}$ terminus of the coat protein are tolerated and mutants cause more severe symptoms than the wild type virus in several hosts [54, 55]. Alternatively, in the absence of coinfecting viruses, in SCMV deletions between the $\mathrm{C}$ terminus of NIb and the $\mathrm{N}$ terminus of the coat protein may be lethal.

Polyprotein alignment showed that the 15-amino acid deletion observed in three Kenya samples (group 3) is present in one isolate from China and in the isolate reported in the original description of maize lethal necrosis in Kenya (JX286708.1) [6] (Fig. 4b). Amino acid variation at the $\mathrm{C}$ terminus of $\mathrm{NIb}$ and at the $\mathrm{N}$ terminus of the coat protein in Kenya group 1 is similar to variation in 
two isolates from Rwanda [9], two from Ethiopia and one from Mexico. Additionally, the 13-amino acid deletion observed in 6 samples from Kenya (group 2) is present in a SCMV isolate from Ethiopia (Fig. 4b). Furthermore, three complete genomes have been described from Ethiopia [11]. In our analysis, they formed a clear cluster between the China and Mexico isolate (Fig. 7b). Interestingly, one isolate from Ethiopia harbors the 13-amino acid deletion described here for 6 Kenya samples (Fig. 4b, group 2). Cloning, sequencing, and restriction digestion analysis of SCMV infecting sugarcane in India [56] and maize in Brazil [57] showed that the $\mathrm{N}$ terminus of the coat protein is hypervariable. A similar analysis showed genetic diversity in SCMV coat protein sequence in Cameroon and Congo [58]. These observations show that SCMV harbors a hypervariable region between NIb and the coat protein.

Variation at the $\mathrm{C}$ terminus of $\mathrm{NIb}$ and $\mathrm{N}$ terminus of the coat protein in SCMV could explain inconsistent detection of SCMV by ELISA [19, 21, 22], and failure to detect SCMV in Rwanda [9] (similar to group 1) by RTPCR using primers designed for Kenya group 3. These observations highlight the need to raise antibodies against African isolates and universal primers to detect SCMV. Alternatively, or in addition, plants showing maize lethal necrosis symptoms could be infected by other potyviruses. In addition to SCMV, other potyviruses found in Kenya samples include were Hubei Poty-like virus 1, Scallion mosaic virus and JGMV (Fig. 1d). Interestingly, JGMV in combination with MCMV, causes maize lethal necrosis [19]. The role of other potyviruses in maize lethal necrosis remains to be determined.

Screening of germplasm and commercial hybrids for resistance to maize lethal necrosis has focused on MCMV and SCMV [5, 24-26]. The widespread distribution of MYDV-RMV, MSV, and possibly JGMV (Fig. 2b) [21] highlights the need to include other viruses in breeding programs seeking to develop virus-resistant cultivars or hybrids for East Africa.

Multiple sources of virus may contribute to maize lethal necrosis epidemic. Soil and seed transmission is possible for both MCMV and SCMV [5, 59]. Additionally, both potyviruses and poleroviruses are transmitted by aphids [50,60]. MCMV is transmitted by several species of beetles in the family Chysomelidae [61] and by western flower thrips (Frankliniella occidentallis) [62]. Despite lacking visible viral symptoms, the three sorghum samples we analyzed (Fig. 1c) contained MCMV, SCMV, MSV and MYDV-RMV. Similarly, one asymptomatic napier grass sample contained MCMV (Fig. 2). Consistent with these observations, several grass species and sorghum cultivars were determined to be asymptomatic hosts for MCMV, SCMV and WSMV [5, 59]. Thus, sorghum, napier grass and possible other grass species are virus reservoirs for insect vectors to spread the viruses to maize. Several factors, including genotype, plant age and days after infection at the time samples were collected, may contribute to the absence of symptoms in our sorghum and napier grass samples. Further experimentation is needed to determine the response of sorghum and napier grass to viruses that cause maize lethal necrosis and to understand their role as alternate hosts.

Although MCMV, SCMV, WSMV and JGMV are present, maize production is not reduced due to maize lethal necrosis in the United States [63, 64]. After the initial detection in Kansas and Nebraska in the 1970's [65], maize lethal necrosis was managed by a combination of agronomic practices that included crop rotation, removal of alternate hosts, and use of hybrids tolerant to MCMV or SCMV $[65,66]$. Epidemiological models and field surveys show that growing maize continually results in an increase of virus inoculum $[5,63]$. Consistent with these observations, crop rotation could reduce the prevalence and delay infection [63]. However, in East Africa, maize is grown year-round during two growing seasons, underscoring the need to develop integrated management strategies to slow the spread and damage caused by maize lethal necrosis. The strategy must include identification and deployment of virus tolerant germplasm, seed sanitation and distribution programs, identification and removal of alternates, and insect vector control, and the establishment of a systematic surveillance program. SCMV in Kenya are genetically different to isolates from other parts of the world (Fig. 4). Thus, phytosanitary regulations could be implemented on maize and sorghum grain imports. These measures require rapid and reliably diagnosis. Sequences described here provide a solid foundation to develop global, directed multiplex nucleic acid-based methods to diagnose MCMV, SCMV, MSV, MYDV-RMV and closely related viruses.

\section{Conclusions}

The maize lethal necrosis epidemic in Kenya is complex. In addition to MCMV and SCMV, several other potyviruses and possibly poleroviruses are involved (Fig. 1). Sorghum, napier grass and possibly other plant species participate as alternate hosts. SCMV is widely distributed in Kenya (Fig. 1b) and consists of numerous strains that are genetically different to isolates from other parts of the world (Fig. 7b). SCMV harbors a hypervariable region at the border between NIb and the coat protein. These observations provide a solid foundation to design integrated disease management strategies, and have potential to impact breeding programs aiming to developing SCMV resistance, diagnostic protocols, and quarantine regulations. 


\section{Additional files}

Additional file 1: Figure S1. A schematic representation of sampling strategy, RNA sequencing, analysis, and virus identification. (PDF 301 kb)

Additional file 2: Table S1. Description of samples used for identification of viruses associated to maize lethal necrosis in Kenya by a metagenomic analysis. (XLSX $1273 \mathrm{~kb}$ )

Additional file 3: Figure S2. Size and frequency of de novo-assembled representative contigs with high similarity to known viruses. In total 68 samples were sequenced and analyzed. Contig size is represented in 0.5 $\mathrm{Kb}$ increments in the $\mathrm{X}$ axis. The $\mathrm{Y}$ axis represents the number of contigs per size class. For each virus, the number of samples categorized as infected is indicated. a MCMV. b SCMV. c MSV. d MYDV-RMV. (PDF 278 kb)

Additional file 4: Table S2. Virus identification by Blast $N$ against the Plant Virus Genome Database and contig alignment. (XLSX 1123 kb)

Additional file 5: MCMV contigs used for phylogenetic analysis. (FASTA $132 \mathrm{~kb}$ )

Additional file 6: SCMV contigs used for phylogenetic analysis. (FASTA $193 \mathrm{~kb}$ )

Additional file 7: Figure S3. Partial nucleotide sequence alignment of Kenya samples in group 1, 2 and 3 relative to the Ohio isolate of SCMV (JX188385.1). The coat protein detected in the original description of maize lethal necrosis in Kenya was used for comparison (JX286708.1) [6] Alignment was generate using MAFFT. NIb and coat protein coding sequences are color coded blue and red, respectively. Coordinates are based on the Ohio isolate (JX188385.1). In group 1 no nucleotide insertions or deletions were observed. Nucleotide substitutions resulted in amino acid substitutions. Group two, had a $39 \mathrm{nt}$ deletion (8487 to 8525 ) that resulted in an in-frame deletion of 13 amino acids. Group 3 , had low similarity and a 45 nt deletion between nt 8487 to 8676 that resulted in a 15-amino acid deletion. (PDF $256 \mathrm{~kb}$ )

Additional file 8: MSV contigs used for phylogenetic analysis. (FASTA $20 \mathrm{~kb}$ )

Additional file 9: MYDV-RMV contigs used for phylogenetic analysis. (FASTA $27 \mathrm{~kb}$ )

\section{Acknowledgements}

We thank the Director General KALRO for spearheading the Research and supporting study leave for Mwathi Jane Wamaitha, and Dr. Rob Skilton for guidance. The Biosciences Eastern and Central Africa-International Livestock Research Institute (BecA-ILRI) Hub, Nairobi, for Next generation sequencing. Mwathi Jane Wamaitha was the recipient of a Borlaug International Agricultural Science and Technology fellowship (2017) from the USDA Foreign Agricultural Service. The bioinformatics work was completed, through HGR lab, at the Holland Computing Center of the University of Nebraska-Lincoln, which receives support from the Nebraska Research Initiative.

\section{Funding}

Sampling was supported by the Government of Kenya (GoK) through a competitive World Bank Supported program, Kenya Agricultural Productivity and Agribusiness collaborative research Project (KAPAP-CGS Grant (2014-2015) through Kenya Agricultural and Livestock Research Organization (KALRO) as the lead organization, collaborating with Ministry of Agriculture, Livestock and Fisheries-PPSD, KELPHIS, PCPB, ICIPE and University of Nairobi. The NGS was supported by BecA-ILRI Hub through the Africa Biosciences Challenge Fund (ABCF) program. The ABCF Program is funded by the Australian Department for Foreign Affairs and Trade (DFAT) through the BecA-CSIRO partnership; the Syngenta Foundation for Sustainable Agriculture (SFSA); the Bill \& Melinda Gates Foundation (BMGF); the UK Department for International Development (DFID) and the Swedish International Development Cooperation Agency (SIDA). The Bioinformatics analysis was supported by Borlaug International Agricultural Science and Technology fellowship (2017) from the USDA Foreign Agricultural Service to MJW hosted by the HGR lab. HGR lab is supported by NIH grant RO1GM120108 and by the Nebraska Agricultural Experiment Station with funding from the
Hatch Act (Accession Number 1007272) through the USDA National Institute of Food and Agriculture.

\section{Availability of data and materials}

RNAseq raw data is available at NCBI, Bioproject ID: PRJNA42371. Complete genomes were deposited in GenBank for MCMV (MH205605), SCMV (MG932076, MG932077, MG932078, MG932079, MG932080, and MH205604), MSV (MH205606) and MYDV-RMV (MH205607).

\section{Authors' contributions}

Conceived and designed experiments: MJW, FS, and MW. Collected and processed samples: MJW, AW, BWW, and SM. Contributed reagents/ materials/analysis tools: MJW, DN, HGR, JNN, TAH, TL, and AD. Analyzed the data: HGR, DN, and MJW. Wrote the manuscript: HGR, MJW, and DN. All authors read and approved the final manuscript.

\section{Ethics approval and consent to participate}

Not applicable.

\section{Competing interests}

The authors declare that they have no competing interests.

\section{Publisher's Note}

Springer Nature remains neutral with regard to jurisdictional claims in published maps and institutional affiliations.

\section{Author details}

${ }^{1}$ Kenya Agricultural and Livestock Research Organization (KALRO), P. O. Box 14733-00800, Nairobi, Kenya. ${ }^{2}$ Department of Plant Pathology and Nebraska Center for Virology, University of Nebraska- Lincoln, Lincoln, NE 68583, USA ${ }^{3}$ School of Agriculture and Environment and UWA Institute of Agriculture, Faculty of Science, The University of Western Australia, 35 Stirling Highway, Crawley, WA 6009, Australia. ${ }^{4}$ Cooperative Research Centre for Plant Biosecurity, Canberra ACT 2617, Australia. ${ }^{5}$ Biosciences Eastern and Central Africa-International Livestock Research Institute (BecA-ILRI), Hub, Nairobi, Kenya. ${ }^{6}$ Plant Innovation Centre, Post-Entry Quarantine, Department of Agriculture and Water Resources, 135 Donnybrook Road, Mickleham, VIC 3064, Australia. ${ }^{7}$ Centre for Tropical Livestock Genetics and Health (CTLGH), The University of Edinburgh, Edinburgh, Scotland EH25 9RG, UK.

Received: 25 January 2018 Accepted: 7 May 2018

Published online: 23 May 2018

\section{References}

1. Smale M, Byerlee D, Jayne T. Maize revolutions in sub-Saharan Africa. In An African Green Revolution. Keijiro Otsuka and Donald F. Larson (editors). London: Springer; 2011.

2. Nuss ET, Tanumihardjo SA. Quality protein maize for africa: closing the protein inadequacy gap in vulnerable populations. Adv Nutr. 2011;2:217-24. https://doi.org/10.3945/an.110.000182

3. Alexandratos N, Bruinsma J. World agriculture towards 2030/2050: the 2012 revision. Agriculture Economics Division. Food and Agriculture Organization of the United Nations. ESA Working paper No. 12-03. Rome, Italy. 2012.

4. Shiferaw B, Prasanna BM, Hellin J, Bänziger M. Crops that feed the world 6. Past successes and future challenges to the role played by maize in global food security. Food Sec. 2011;3:307.

5. Mahuku G, Lockhart BE, Wanjala B, Jones MW, Kimunye JN, Stewart LR, Cassone BJ, Sevgan S, Nyasani JO, Kusia E, et al. Maize lethal necrosis ( $\mathrm{mln})$, an emerging threat to maize-based food security in sub-saharan africa. Phytopathology. 2015;105:956-65.

6. Adams IP, Miano DW, Kinyua ZM, Wangai A, Kimani E, Phiri N, Reeder R, Harju V, Glover R, Hany U, et al. Use of next-generation sequencing for the identification and characterization ofmaize chlorotic mottle virusandsugarcane mosaic viruscausing maize lethal necrosis in Kenya. Plant Pathol. 2013:62:741-9.

7. Wangai AW, Redinbaugh MG, Kinyua ZM, Miano DW, Leley PK, Kasina M, Mahuku G, Scheets K, Jeffers D. First report of maize chlorotic mottle virus and maize lethal necrosis in Kenya. Plant Dis. 2012;96:1582-3.

8. Kagoda F, Gidoi R, Isabirye BE. Status of maize lethal necrosis in eastern Uganda. Afr J Agric Res. 2016;11:652-60. 
9. Adams I, Harju V, Hodges T, Hany U, Skelton A, Rai S, Deka M, Smith J, Fox A, Uzayisenga B. First report of maize lethal necrosis disease in Rwanda. New Dis Rep. 2014;29:22.

10. Lukanda M, Owati A, Ogunsanya P, Valimunzigha K, Katsongo K, Ndemere $H$, Kumar PL. First report of maize chlorotic mottle virus infecting maize in the Democratic Republic of the Congo. Plant Dis. 2014;98:1448.

11. Mahuku G, Wangai A, Sadessa K, Teklewold A, Wegary D, Adams I, Smith J, Braidwood L, Feyissa B, Regassa B. First report of maize chlorotic mottle virus and maize lethal necrosis on maize in Ethiopia. Plant Dis. 2015;99:1870.

12. Niblett C, Claflin L. Corn lethal necrosis-a new virus disease of corn in Kansas. Plant Dis Rep. 1978;62:15-9.

13. Dawson N, Martin A, Sikor T. Green revolution in sub-saharan africa: implications of imposed innovation for the wellbeing of rural smallholders. World Dev. 2016:78:204-18.

14. Frankema E. Africa and the green revolution a global historical perspective. NJAS-Wageningen J Life Sci. 2014;70:17-24.

15. Frelat R, Lopez-Ridaura S, Giller KE, Herrero M, Douxchamps S, Djurfeldt AA Erenstein O, Henderson B, Kassie M, Paul BK. Drivers of household food availability in sub-saharan africa based on big data from small farms. Proc Natl Acad Sci. 2016;113:458-63.

16. Sibanda OS. Trade liberalisation and its impact on food security in subsaharan africa. Int J Public Law Policy. 2015:5:92-107.

17. Nutter $R$, Scheets K, Panganiban L, Lommel S. The complete nucleotide sequence of the maize chlorotic mottle virus genome. Nucleic Acids Res. 1989;17:3163-77.

18. Stenger DC, Young BA, Qu F, Morris TJ, French R. Wheat streak mosaic virus lacking helper component-proteinase is competent to produce disease synergism in double infections with maize chlorotic mottle virus. Phytopathology. 2007;97:1213-21.

19. Stewart LR, Willie K, Wijeratne S, Redinbaugh MG, Massawe D, Niblett CL, Kiggundu A, Asiimwe T. Johnsongrass mosaic virus contributes to maize lethal necrosis in east africa. Plant Dis. 2017;101:1455-62.

20. Adams I, Miano D, Kinyua Z, Wangai A, Kimani E, Phiri N, Reeder R, Harju V, Glover R, Hany U. Use of next-generation sequencing for the identification and characterization of maize chlorotic mottle virus and sugarcane mosaic virus causing maize lethal necrosis in Kenya. Plant Pathol. 2013;62:741-9.

21. Adams I, Braidwood L, Stomeo F, Phiri N, Uwumukiza B, Feyissa B, Mahuku G, Wangai A, Smith J, Mumford R, et al. Characterising maize viruses associated with maize lethal necrosis symptoms in sub saharan africa. bioRxiv. 2017; https://doi.org/10.1101/161489

22. Fentahun M, Feyissa T, Abraham A, Kwak HR. Detection and characterization of maize chlorotic mottle virus and sugarcanemosaic virus associated with maize lethal necrosis disease in Ethiopia: an emerging threat to maize production in the region. Eur J Plant Pathol. 2017:1-7.

23. Zambrano JL, Jones MW, Brenner E, Francis DM, Tomas A, Redinbaugh MG. Genetic analysis of resistance to six virus diseases in a multiple virusresistant maize inbred line. Theor Appl Genet. 2014;127:867-80.

24. Semagn K, Beyene Y, Babu R, Nair S, Gowda M, Das B, Tarekegne A, Mugo S, Mahuku G, Worku M. Quantitative trait loci mapping and molecular breeding for developing stress resilient maize for sub-saharan africa. Crop Sci. 2015;55:1449-59.

25. Beyene Y, Gowda M, Suresh LM, Mugo S, Olsen M, Oikeh SO, Juma C, Tarekegne A, Prasanna BM. Genetic analysis of tropical maize inbred lines for resistance to maize lethal necrosis disease. Euphytica. 2017:213:224.

26. Jones MW, Penning BW, Jamann TM, Glaubitz JC, Romay C, Buckler ES, Redinbaugh M. Diverse chromosomal locations of quantitative trait loci for tolerance to maize chlorotic mottle virus in five maize populations. Phytopathology. 2017;

27. Liu Q, Liu H, Gong Y, Tao Y, Jiang L, Zuo W, Yang Q, Ye J, Lai J, Wu J, et al. An atypical thioredoxin imparts early resistance to sugarcane mosaic virus in maize. Mol Plant. 2017;10:483-97.

28. Nagano AJ, Honjo MN, Mihara M, Sato M, Kudoh H. Detection of plant viruses in natural environments by using rna-seq. In: Uyeda I, Masuta C, editors. Plant virology protocols: new approaches to detect viruses and host responses. New York: Springer New York; 2015. p. 89-98.

29. Maina S, Edwards OR, de Almeida L, Ximenes A, Jones RAC. First complete squash leaf curl China virus genomic segment DNA-a sequence from East Timor. Genome Announcements. 2017;5:e00483-17.

30. Andrews SF, Krueger F, Seconds-Pichon A, Biggins F, Wingett SF. A quality control tool for high throughput sequence data. Babraham Bioinformatics.
2014. Available online at: http://www.bioinformatics.babraham.ac.uk/ projects/fastqc

31. Bolger AM, Lohse M, Usadel B. Trimmomatic: a flexible trimmer for illumina sequence data. Bioinformatics. 2014;30:2114-20.

32. Grabherr MG, Haas BJ, Yassour M, Levin JZ, Thompson DA, Amit I, Adiconis X, Fan L, Raychowdhury R, Zeng Q. Trinity: reconstructing a full-length transcriptome without a genome from rna-seq data. Nat Biotechnol. 2011;29:644.

33. Li H, Handsaker B, Wysoker A, Fennell T, Ruan J, Homer N, Marth G, Abecasis G, Durbin R, Genome Project Data Processing, S. The sequence alignment/ map format and samtools. Bioinformatics. 2009;25:2078-9.

34. Robinson JT, Thorvaldsdóttir H, Winckler W, Guttman M, Lander ES, Getz G, Mesirov JP. Integrative genomics viewer. Nat Biotechnol. 2011;29:24-6.

35. Kamitani M, Nagano AJ, Honjo MN, Kudoh H. Rna-seq reveals virus-virus and virus-plant interactions in nature. FEMS Microbiol Ecol. 2016:92:fiw176.

36. Katoh K, Toh H. Recent developments in the mafft multiple sequence alignment program. Brief Bioinform. 2008;9:286-98.

37. Braidwood LA, Quito-Avila DF, Cabanas D, Bressan A, Wangai A, Baulcombe DC. A first global phylogeny of <em> maize chlorotic mottle virus </em>. bioRxiv. 2017; https://doi.org/10.1101/209940.

38. Huson DH, Bryant D. Application of phylogenetic networks in evolutionary studies. Mol Biol Evol. 2006:23:254-67.

39. Ronquist F, Teslenko M, van der Mark P, Ayres DL, Darling A, Hohna S, Larget B, Liu L, Suchard MA, Huelsenbeck JP. Mrbayes 3.2: efficient bayesian phylogenetic inference and model choice across a large model space. Syst Biol. 2012;61:539-42.

40. Chung BY, Miller WA, Atkins JF, Firth AE. An overlapping essential gene in the potyviridae. Proc Natl Acad Sci U S A. 2008;105:5897-902.

41. Pande D, Madzokere E, Hartnady P, Kraberger S, Hadfield J, Rosario K, Jaschke A, Monjane AL, Owor BE, Dida MM, et al. The role of Kenya in the trans-african spread of maize streak virus strain a. Virus Res. 2017;232:69-76.

42. Shi XM, Miller H, Verchot J, Carrington JC, Vance VB. Mutations in the region encoding the central domain of helper component-proteinase (hc-pro) eliminate potato virus x/potyviral synergism. Virology. 1997;231:35-42.

43. Murphy JF, Bowen KL. Synergistic disease in pepper caused by the mixed infection of cucumber mosaic virus and pepper mottle virus. Phytopathology. 2006;96:240-7.

44. Zhang X, Du P, Lu L, Xiao Q, Wang W, Cao X, Ren B, Wei C, Li Y. Contrasting effects of hc-pro and $2 b$ viral suppressors from sugarcane mosaic virus and tomato aspermy cucumovirus on the accumulation of sirnas. Virology. 2008; 374:351-60.

45. Tatineni S, Qu F, Li R, Morris TJ, French R. Triticum mosaic poacevirus enlists p1 rather than hc-pro to suppress rna silencing-mediated host defense. Virology. 2012;433:104-15.

46. Chen S, Jiang G, Wu J, Liu Y, Qian Y, Zhou X. Characterization of a novel polerovirus infecting maize in China. Viruses. 2016;8:120.

47. Scheets K. Analysis of gene functions in maize chlorotic mottle virus. Virus Res. 2016;222:71-9.

48. Boulton Ml. Functions and interactions of mastrevirus gene products. Physiol Mol Plant Pathol. 2002;60:243-55.

49. Liu Y, Jin W, Wang L, Wang X. Replication-associated proteins encoded by wheat dwarf virus act as rna silencing suppressors. Virus Res. 2014;190:34-9.

50. Krueger E, Beckett R, Gray S, Miller WA. The complete nucleotide sequence of the genome of barley yellow dwarf virus-rmv reveals it to be a new polerovirus distantly related to other yellow dwarf viruses. Front Microbiol. 2013;4:205.

51. Wang F, Zhou BG, Gao ZL, Xu DF. A new species of the genus polerovirus causing symptoms similar to maize yellow dwarf virus-rmv of maize in China. Plant Dis. 2016;100:1508.

52. Yahaya A, Al Rwahnih M, Dangora DB, Gregg L, Alegbejo MD, Lava Kumar $P$, Alabi OJ. First report of maize yellow mosaic virus infecting sugarcane (saccharum spp.) and itch grass (rottboellia cochinchinensis) in Nigeria. Plant Dis. 2017;101:1335

53. Ivanov Kl, Eskelin K, Lohmus A, Makinen K. Molecular and cellular mechanisms underlying potyvirus infection. J Gen Virol. 2014;95:1415-29.

54. Tatineni S, Elowsky C, Graybosch RA. Wheat streak mosaic virus coat protein deletion mutants elicit more severe symptoms than wild-type virus in multiple cereal hosts. Mol Plant-Microbe Interact. 2017:30:974-83.

55. Tatineni S, Kovacs F, French R. Wheat streak mosaic virus infects systemically despite extensive coat protein deletions: identification of virion assembly and cell-to-cell movement determinants. J Virol. 2014;88:1366-80. 
56. Viswanathan R, Karuppaiah R, Balamuralikrishnan M. Identification of new variants of scmv causing sugarcane mosaic in India and assessing their genetic diversity in relation to scmv type strains. Virus Genes. 2009;39:375.

57. Gonçalves MC, Galdeano DM, Maia IdG, Chagas CM. Variabilidade genética de sugarcane mosaic virus, causando mosaico em milho no brasil. Pesq Agrop Brasileira. 2011;46:362-9.

58. Alegria OM, Royer M, Bousalem M, Chatenet M, Peterschmitt M, Girard J-C, Rott P. Genetic diversity in the coat protein coding region of eighty-six sugarcane mosaic virus isolates from eight countries, particularly from Cameroon and Congo. Arch Virol. 2003;148:357-72.

59. Bockelman DL. Host range and seed-transmission studies of maize chlorotic mottle virus in grasses and corn. Plant Dis. 1982;66:216.

60. Brault V, Perigon S, Reinbold C, Erdinger M, Scheidecker D, Herrbach E, Richards K, Ziegler-Graff V. The polerovirus minor capsid protein determines vector specificity and intestinal tropism in the aphid. J Virol. 2005:79:9685-93.

61. Nault LR, Styer WE, Coffey ME, Gordon DT, Negi LS, Niblett CL. Transmission of maize chlorotic mottle virus by chrysomelid beetles. Phytopathology. 1978;68:1071-4

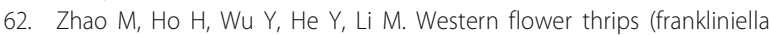
occidentalis) transmits maize chlorotic mottle virus. J Phytopathol. 2014; 162:532-6.

63. Hilker FM, Allen LJS, Bokil VA, Briggs CJ, Feng Z, Garrett KA, Gross LJ, Hamelin FM, Jeger MJ, Manore CA, et al. Modeling virus coinfection to inform management of maize lethal necrosis in Kenya. Phytopathology. 2017; 107:1095-108.

64. Stewart LR, Teplier R, Todd JC, Jones MW, Cassone BJ, Wijeratne S, Wijeratne A Redinbaugh MG. Viruses in maize and johnsongrass in southern Ohio. Phytopathology. 2014;104:1360-9.

65. Uyemoto JK. Biology and control of maize chlorotic mottle virus. Plant Dis. 1983:67:7-10.

66. Phillips NJ, Uyemoto JK, Wilson DL. Maize chlorotic mottle virus and crop rotation: effect of sorhgum on virus incidence. Plant Dis. 1982;66:376-9.

\section{Ready to submit your research? Choose BMC and benefit from:}

- fast, convenient online submission

- thorough peer review by experienced researchers in your field

- rapid publication on acceptance

- support for research data, including large and complex data types

- gold Open Access which fosters wider collaboration and increased citations

- maximum visibility for your research: over $100 \mathrm{M}$ website views per year 